\title{
1 Vegetation patterns along micro-relief and tree-line 2 transects in polygonal landscapes of the Siberian Arctic
}

\section{Journal of Vegetation Science}

Author names and addresses:

5

\section{Romy Zibulski, Ulrike Herzschuh, Luidmila Pestryakova}

Romy Zibulski (corresponding author, Romy.Zibulski@awi.de, Alfred-Wegener-Institut, HelmholtzZentrum für Polar- und Meeresforschung, 14473 Potsdam, Germany)

Ulrike Herzschuh (Ulrike.Herzschuh@awi.de, Alfred-Wegener-Institut, Helmholtz-Zentrum für Polar- und Meeresforschung, 14473 Potsdam, Germany; University of Potsdam, Institute of Earth and Environmental Sciences, 14476 Potsdam-Golm, Germany)

Luidmila A. Pestryakova (lapest@mail.ru, Northeast Federal University, Department for Geography and Biology, 677000 Yakutsk, Russia)

\section{Abstract}

Question: How do absolute cover, alpha-diversity, and the compositional turnover of vascular plants and bryophytes change along micro-relief levels (rim to pond) within polygons in northern Siberia located along a vegetation gradient from open larch forests to subarctic tundra?

Methods: In total, 152 one square-metre vegetation plots were investigated in eight low-centred polygons located south of the Taymyr Peninsula and on Samoylov Island in the Lena River delta in northern Siberia.

Results: The cover of vascular plants displays no significant differences between the rim and rimpond transition but is significantly lower in the pond. Their alpha-diversity decreases strongly from rim to pond in the polygons. We found no trend in vascular plant cover from open forest to tundra vegetation and only a slightly decreasing trend for alpha-diversity. Bryophyte cover and alphadiversity are highest on the rim and significantly distinct from the pond, but not from the rim-pond transition. There is no clear trend in cover or alpha-diversity along the tree-line transect. Separate 
ordinations of the vascular plant and bryophyte composition data indicate that both the micro-scale relief gradient (within each polygon) as well as the regional-scale vegetation gradient (across the tree line) is reflected by the vegetation composition. The micro-relief gradient explains a slightly higher variance of vegetation composition as revealed by a series of partial redundancy analyses than the vegetation type over the subarctic tundra, in particular with respect to bryophytes.

The applied indicator species analysis identified characteristic taxa of certain environmental conditions and combinations of them. We found that 26 vascular plant and 22 bryophyte taxa are characteristic for the three individual micro-relief levels, and 28 vascular plant and 24 bryophyte taxa are characteristic for single vegetation types.

Conclusions: The observed gradual pattern in alpha-diversity and composition of polygonal vegetation suggests that the local water regime is the main driver of changes in vegetation composition while regional temperature and related forest-cover change is of subordinate importance for polygonal vegetation-type patterns.

\section{Keywords:}

vascular plants; bryophytes; indicator species; low-centred polygon; NMDS; arctic vegetation; tree line; tundra; Siberia; Russia

\section{Nomenclature:}

USDA, NRCS. 2014. The PLANTS Database (http://plants.usda.gov)

\section{Introduction}

Euarctic or hyperarctic vegetation is assumed to be particularly vulnerable to climate change (Sturm et al. 2001; Callaghan et al. 2004) i.e. it is expected that the northern boreal forest zone will become more dense and spread northward into the arctic tundra (MacDonald et al. 2000; Kharuk et al. 2006). Such changes would entail strong effects not only on a regional, but also on a global scale due to complex vegetation-climate feedbacks (Bonan et al. 1992; Foley et al. 1994). For example, along with shrub and forest establishment the albedo decreases, which affects the energy budgets of permafrost 
soils leading to changes in microbial decomposition and methane release (Oechel et al. 1993; Betts 2000; Smith et al. 2004). Accordingly, vegetation transect studies across the tree line help to approximate better the ongoing and future changes. However, such investigations are lacking for the vast polygonal landscapes of northern Siberia, even though vegetation-change related effects on methane release in these regions would be of particular relevance for global climate because of the tremendous fossil carbon storage in the ice-rich deposits underlying most of these areas (Grosse et al. 2006).

The Siberian Lowlands are characterized by low-centred polygons resulting from the interaction between the sub-continental climate and permafrost conditions. Here, very low and rapidly falling winter temperatures in combination with only a thin snow cover leads to tensions in the soil generating a regular crack pattern. Filling of the cracks by melt-water in spring and summer and recurring freezing during the follwoing winter leads to the formation of ice-veins that grow, over time, to icewedges (Minke et al. 2007; French 2007). Frost-heave forces the overlying soil layer up to form polygon rims. Hence the centre of the polygon has a lower elevation and is often filled by water. The slow decomposition of organic matter due to water-logged conditions with a permanent exclusion of oxygen leads to the long-term deposition of organic matter in such landscapes. Palaeoecological studies using these sediments show that the position of polygonal centres and rims are stable on decadal to millennial time-scales (Minke et al. 2009; Zibulski et al. 2013).

Bryophytes are important components of polygonal vegetation both in terms of modern diversity and vegetation cover. Their remains dominate peaty deposits (de Klerk et al. 2011; Zibulski et al. 2013) and because of their climate-relevant carbon sink/release function, they are of significance for high-latitude vegetation-climate feedback mechanisms. However, the taxonomic composition of arctic bryophytes and their relationship with environmental gradients have seldom been taken into account in environmental investigations of modern and fossil material.

The guiding questions of this vegetation study from northern Siberia are: 1) how do absolute cover, alpha-diversity, and the composition of vascular plants and bryophytes change along a microrelief transect within low-centred polygons, 2) how do total vascular plant and bryophyte cover, alpha- 
diversity and composition change along a regional scale (tree line) transect, and 3 ) is the information

gained useful for environmental reconstructions and predictions?

Material and methods

82

83

\section{Regional setting}

Two areas in North Siberia were investigated: a tree-line transect (Fig. 1) across different vegetation types in the lower Khatanga River region $\left(70-72^{\circ}\right.$ N, $97-102^{\circ}$ E) and on Samoylov Island in the Lena River delta $\left(72.4^{\circ} \mathrm{N}, 126.5^{\circ} \mathrm{E}\right)$. In total, six polygons in the Khatanga region were studied and two on Samoylov Island. The Khatanga study area extends along the Khatanga River south of the Taymyr Peninsula in the northern Siberian lowlands. Samoylov Island is situated in the southern part of the Lena River delta on a terrace that was formed during the late Holocene (Boike et al. 2013). Both regions are characterized by polygonal wet tundra and thermokarst lakes (Botch et al. 1995; Schwamborn et al. 2002; Boike et al. 2013). The lower elevated western part of Samoylov becomes flooded each spring whereas the higher terraces of the island are affected only during extreme flooding events (Kutzbach et al. 2004) and during these rare events, allochthonous material may be washed in.

Table 1: Short description of studied polygons.

\begin{tabular}{|c|c|c|}
\hline Polygon & coord & $\begin{array}{l}\text { short description } \\
\text { site; vegetation type; distance to nearby water features; transect length; additional } \\
\text { information }\end{array}$ \\
\hline $06 / \mathrm{P}$ & $\begin{array}{l}70.666^{\circ} \mathrm{N} \\
97.708^{\circ} \mathrm{E}\end{array}$ & $\begin{array}{l}\text { Khatanga; open forest; } 240 \mathrm{~m} \text { to nameless lake; } 26 \mathrm{~m} \text {; swinging bog on an aggradation } \\
\text { plain of a lake at the edge of an elevated larch forest (tallest trees: } 12 \mathrm{~m} \text { ) }\end{array}$ \\
\hline $17 / \mathrm{P}$ & $\begin{array}{l}72.243^{\circ} \mathrm{N} \\
102.233^{\circ} \mathrm{E}\end{array}$ & $\begin{array}{l}\text { Khatanga; forest-tundra intersection; } 110 \mathrm{~m} \text { to nameless lake; } 13 \mathrm{~m} \text {; shallow polygon; } \\
\text { located on aggradation plain of a lake at the edge of an elevated larch forest with low } \\
\text { cover }\end{array}$ \\
\hline P3 & $\begin{array}{l}72.149^{\circ} \mathrm{N} \\
102.693^{\circ} \mathrm{E}\end{array}$ & $\begin{array}{l}\text { Khatanga; forest-tundra intersection; P3/I: } 630 \mathrm{~m}, \mathrm{P} 3 / \mathrm{II}: 610 \mathrm{~m}, \mathrm{P} 3 / \mathrm{III}: 590 \mathrm{~m} \text { to } \\
\text { Khatanga River; } 63 \mathrm{~m} \text { (a complex of three polygons along a transect with P3/I: } \\
1-22 \mathrm{~m} \text { (deep centre, open water body without vegetation), P3/II: } 23-45 \mathrm{~m} \text { (shallow } \\
\text { polygon, open water body without vegetation), P3/III: } 46-63 \mathrm{~m} \text { (shallow and } \\
\text { completely vegetated polygon)); in a polygon field within an old meander belt }\end{array}$ \\
\hline $12 / \mathrm{P}$ & $\begin{array}{l}72.431^{\circ} \mathrm{N} \\
102.373^{\circ} \mathrm{E}\end{array}$ & $\begin{array}{l}\text { Khatanga; tundra; } 70 \mathrm{~m} \text { to nameless thermokarst lake; } 29 \mathrm{~m} \text {; shallow; southwards of } \\
\text { the Novaya River, a northern tributary of the Khatanga River in a broad thermokarst } \\
\text { depression connecting several lakes, infrequent isolated groups of larch krummholz in } \\
\text { the surrounding area }\end{array}$ \\
\hline LP1 & $\begin{array}{l}72.375^{\circ} \mathrm{N} \\
126.483^{\circ} \mathrm{E}\end{array}$ & $\begin{array}{l}\text { Samoylov Island (Lena River delta); tundra; } 50 \mathrm{~m} \text { to 'fish lake' (unofficial name) and } \\
820 \mathrm{~m} \text { to Lena River; } 19 \mathrm{~m} \text {; deep polygon centre with an open water area; on a late- }\end{array}$ \\
\hline
\end{tabular}


Holocene terrace, at the margin of the thermokarst depression around the 'fish lake'

LP2 $\quad 72.370^{\circ} \mathrm{N}, \quad$ Samoylov Island (Lena River delta); tundra; $140 \mathrm{~m}$ to 'Banja lake' (unofficial name) $126.481^{\circ} \mathrm{E} \quad$ and $250 \mathrm{~m}$ to Lena River; $19 \mathrm{~m}$; shallow; on a late-Holocene terrace, without an open water area

94

95

The climate of the study area is characterized by strong seasonal contrasts despite its proximate location to the Laptev Sea. Both regions are humid with a precipitation peak in July (annual precipitation of Khatanga: $272 \mathrm{~mm}$ (Rivas-Martinez \& Rivas-Saenz 2007); annual precipitation of Samoylov: $232.7 \mathrm{~mm}$ (Boike et al. 2013)) though the water availability for plants is limited by temperatures below $0^{\circ} \mathrm{C}$ for approximately 8.5 to 9 months each year. The average annual temperature of Khatanga is $-13.2^{\circ} \mathrm{C}$ (Rivas-Martinez \& Rivas-Saenz 2007) and of Samoylov it is $-12.5^{\circ} \mathrm{C}$ (Boike et al. 2013).

Study site locations extend along a vegetation gradient (Matveev, 1989; Mutke \& Barthlott 2005) from open larch forests $\left(<70.5^{\circ} \mathrm{N}\right)$ to subarctic tundra $\left(>72.3^{\circ} \mathrm{N}\right)$ connected by a forest-tundra intersection zone. Samoylov is treeless subarctic tundra. The longitudinal vegetation compositional turnover between these areas is low according to Matveyeva \& Chernov (2000).

\section{Field methods and environmental data collection}

Field work in the Khatanga area lasted from mid-July to mid-August in 2011 and on Samoylov it was completed in July 2012. For all polygons representative transects (from rim to rim), divided into 1 square metre plots, were selected by visual inspection. The plot size chosen is a balance for vegetation surveys of both plant groups (vascular plants and bryophytes).

Environmental information (surface elevation, thaw depth, water depth) was measured at the centre of each plot relative to a reference line and calibrated to the water level (Fig. 2). (It was impossible to recognize the water-sediment transition at $06 / \mathrm{P}$ because of a dense bryophyte swinging mat. Therefore, we estimated an average height for the three micro-relief levels by applying the height/thaw depth relations gained from roughly comparable polygon types: LP1 and LP2.) All plots that were located $\geq 6 \mathrm{~cm}$ over the water level were classified as rim, all plots with water depth $\geq 7 \mathrm{~cm}$ 
as pond and all sites in-between as rim-pond transition. The distance to the nearest water-body (lake or river) was calculated from the middle of the polygon to the bank of the water-body.

119 Vegetation cover of trees, shrubs/herbs and bryophyte layer were recorded for each plot according to the Braun-Blanquet floristic approach (Braun-Blanquet 1964). The plot size necessitated a finer modification to the abundance scale (Reichelt and Wilmanns 1973) to capture the quantitative presence of small bryophytes. Identification of vascular plant taxa and bryophytes in the field was verifed by investigation of herbarium material from the sites after the expedition. Vascular plants were identified using Jäger (2005). For bryophytes, the identification keys of Lobin et al. (1995), Frahm and

America"

(http://www.mobot.org/plantscience/bfna/bfnamenu.htm) were used.

\section{Data analysis}

Data on the Braun-Blanquet scale were transformed to percentages by using the average cover of classes for each of the 152 plots prior to further computations. Occasionally that produced an artificially high cover of slightly $>100 \%$. The cover of trees and the shrub/herb layer were combined to one vascular plant layer. The Shannon Index was calculated in R version 3.1.1 (R Core Team 2014) separately for the recorded vascular plants and bryophytes for the micro relief and vegetation type. Results were analysed by Kruskal-Wallis tests with alpha-adjustment (Benjamini and Hochberg, 1995) for multiple comparisons using the 'agricolae' package (de Mendiburu 2014).

Non-metric multidimensional scaling (NMDS) was applied separately to vascular plant and bryophyte taxa to extract the major patterns in the vegetation with respect to both inter-taxa relationships and relationships among sites. The Bray-Curtis dissimilarity was used to avoid the double-zero problem with regard to the high proportion of rare taxa. All taxa that appear at least 3 times and sum up to at least $10 \%$ cover in the whole data set are included. Non-vegetated plots were removed from the data set prior to analyses (LP1: I09 and I10 and 06/P: 05 and 06). Nominal data such as micro-relief level (rim, rim-pond transition, pond) and vegetation type (open forest, forest- 
142 tundra intersection, tundra) were included as dummy variables. NMDS was performed in R version

143 3.1.1 (R Core Team 2014) using the 'vegan' package (Oksanen 2011; Oksanen et al. 2013).

144 Relationships between plant taxa and environmental characteristics (micro-relief level, vegetation

145 type) were investigated by variance partitioning (Borcard et al. 1992, Legendre 2008) using

146 Redundancy Analysis (RDA) of Hellinger transformed species data (Legendre \& Gallagher 2001)

147 performed in the 'vegan' R package.

148 Indicator species for certain micro-relief levels and combinations of them as well as for certain

149 vegetation types and combinations of them were identified using the IndVal.g correlation coefficient

150 in the indicator species approach according to De Cáceres \& Legendre (2009) implemented in the

151 'indicspecies’ R package version 1.6.7 (De Cáceres et al. 2013).

152 


\section{Results}

\section{Characteristics of polygonal vegetation}

The thaw depth of the southernmost studied polygon 06/P ranges between 13 and $83 \mathrm{~cm}$ (Fig. 2f). The rim vegetation is mainly composed of vascular plants such as Betula nana (37.5\%), various Ericaceae (Vaccinium uliginosum, V. vitis-idaea, Ledum palustre) and bryophytes such as Hylocomium splendens (62.5\%), Pleurozium schreberi (20\%), Sphagnum rubellum, and S. angustifolium (Sphagnopsida add up to 87.5\%). Eriophorum spp. and Aulacomnium palustre obtain the highest cover (37.5\%) in the rim-pond transition. The polygon centre is completely covered by a $20 \mathrm{~cm}$ thick swinging mat formed by Amblystegiaceae (Warnstorfia exannulata with some W. pseudostraminea and Menyanthes trifoliata (each up to 37.5\%)).

Despite the minor micro-relief difference of only $13 \mathrm{~cm}$ in polygon $17 / \mathrm{P}$ (Fig. 2e), there occur marked differences in thaw depth (pond: $55 \mathrm{~cm}$ rim-pond transition: $35 \mathrm{~cm}$ to $65 \mathrm{~cm}$ ) and vegetation composition. The rim-pond transition plots are vegetated by Betula nana (20\%), Carex spp. (37.5\%), and Eriophorum spp. (37.5\%). Aulacomnium palustre (10\%), Calliergon richardsonii (37.5\%), and Drepanocladus revolvens (62.5\%) represent the most common bryophytes. Additionally Dicranum sp. (20\%) and Sphagnopsida (Sphagnum rubellum (10\%) and S. angustifolium (10\%)) occur in rather dry plots. Pond and wet rim-pond transition plots are characterized by sedges and tussocks rising above the water level which supports Drepanocladus revolvens (10\%).

Only a few Larix individuals grow on the rims between the individual polygons at site P3. The three polygons are characterized by differences in surface height and vegetation (Fig. 2d). The crown of a Larix gmelinii tree in P3/I covers much of the rim-pond transition and rim $(\sim 62.5 \%)$. The dominant rim taxa are Betula nana, Alnus viridis ssp. fruticosa, Vaccinium uliginosum, Carex spp. (each up to $37.5 \%$ ), and Dryas punctata $(20 \%)$. For bryophytes we recognize a gradient of dominant species from P3/I with Aulacomnium turgidum and A. palustre (each 62.5\%) and a liverwort cover up to $37.5 \%$. Hylocomium splendens and Tomentypnum nitens (each 62.5\%) characterize the rim in P3/II, whereas the rim of P3/III is of low height and is dominated by Drepanocladus revolvens $(20 \%)$, Scorpidium scorpioides (up to $87.5 \%$ in the lowest rim plots) and Tomentypnum nitens (37.5\%). Carex 
spp. characterize the rim-pond transition with $37.5 \%$ as well as various deciduous shrubs (Betula nana, Alnus viridis ssp. fruticosa, Vaccinium uliginosum) whose cover sums to $10 \%$. The dominant bryophytes are Scorpidium scorpioides (up to $87.5 \%$ in P3/III), Drepanocladus revolvens (37.5\%), and Aulacomnium turgidum (62.5\%). The few vegetated pond plots of P3/I and P3/II are dominated by Scorpidium scorpioides (P3/I: 10\%; P3/II: 37.5\%) and Drepanocladus revolvens (37.5\%).

The northernmost polygon of the Khatanga region 12/P has a gentle micro-relief (Fig. 2c) with a maximum surface height difference of $27 \mathrm{~cm}$ between rim and pond. The thaw depth ranges between $25 \mathrm{~cm}$ on the rim and $61 \mathrm{~cm}$ in the pond. Only Dryas punctata (obtaining cover up to $20 \%$ ) is restricted to the rim. Betula nana (20\%), Salix spp. (20\%), Tomentypnum nitens (62.5\%), and Sphagnum spp. (20\%) occur on the rim and partially in the rim-pond transition together with Eriophorum species (20\%), Carex spp. (62.5\%), and the bryophytes Scorpidium scorpioides (up to 62.5\%), Drepanocladus revolvens (up to $87.5 \%$ ), and Aulacomnium turgidum (20\%). Pond plots are dominated by Carex spp. and Scorpidium scorpioides (each 37.5\%).

The polygons LP1 (Fig. 2b) and LP2 $\left(72.370^{\circ} \mathrm{N}, 126.481^{\circ}\right.$ E; Fig. 2a) are completely different in their micro-relief characteristics. LP1 has a large open water area (maximum water depth at transect: $58 \mathrm{~cm}$ ) with small thaw depths (only 2 to $5 \mathrm{~cm}$ ) in the centre of the polygon, which increase towards marginal pond plots $(12$ to $31 \mathrm{~cm})$ and the rim $(15$ to $45 \mathrm{~cm})$. Various vascular plant taxa were recorded although they do not obtain a high cover (mostly $<5 \%$ per plot). Dryas punctata $(10 \%)$ is common together with Hylocomium splendens $(87.5 \%)$ on the rim. Comarum palustre (10\%) occurs in marginal pond plots, whereas the pond is colonized mainly by Calliergon giganteum $(87.5 \%)$ and Scorpidium scorpioides (87.5\%). Carex species are common in all vegetated plots. LP2 is a shallow low-centred polygon with a completely vegetated water area (maximum water depth: $11 \mathrm{~cm}$ ). The thaw depth varies only slightly (range: 37 to $53 \mathrm{~cm}$ ) having both the maximum and the minimum on the rim. Carex species reach a cover of up to $37.5 \%$ in rim plots and Hylocomium splendens $(87.5 \%)$ is the prevailing bryophyte.The rim-pond transition is characterized by patches of Sphagnum sp. (10\%) and tussocks composed of Aulacomnium palustre (37.5\%), A. turgidum (10\%) or Meesia triquetra (10\%). The pond is sparsely vegetated by Carex aquatilis (20\%), Scorpidium scorpioides (10\%), and Calliergon giganteum (10\%). 


\section{Vegetation cover and its relationships with micro-relief level and vegetation type}

Larix gmelinii, the only tree occurring in the study area, was recorded at 17/P and $\mathrm{P} 3$ where it grew only on the rims and covered $<1 \%(17 / \mathrm{P}), 37.1 \%(\mathrm{P} 3 / \mathrm{I})$, and $0.4 \%(\mathrm{P} 3 / \mathrm{II}$ and $\mathrm{P} 3 / \mathrm{III})$ of the plots. Additonally, open larch forest occurred in the vicinity of $06 / \mathrm{P}$ and $17 / \mathrm{P}$ on elevated slopes, but it rarely occurred in the areas directly surrounding the investigated polygons.

The absolute cover of vascular plants is highest on the rims ranging from $25 \%$ to $97 \%$ with a maximum in the forest-tundra intersection P3/I (Fig. 3). Rim vascular plant vegetation in the open forest and forest-tundra intersection polygons is characterized by a high percentage of deciduous shrubs (mostly between 30\% and 50\%) but evergreen shrubs also occur. Cover of Poales varied throughout the tree-line transect between $4 \%$ and $40 \%$. The vascular plant cover is mostly lower in the rim-pond transition plots, but there is no significant difference between rim and rim-pond transition (Kruskal Wallis test: $\mathrm{p}>0.1$ ). The cover ranges below $30 \%$ in the pond plots where only Poales occur. The cover of pond plots significantly differs from rim plots (Kruskal Wallis with post-hoc test: $\mathrm{p}<0.001$ ) and from rim-pond-transitions (Kruskal Wallis with post-hoc test: $\mathrm{p}<0.01$ ). There are no significant differences in vascular plant cover between the vegetation types (Kruskal Wallis test: $\mathrm{p}>0.1)$

The bryophyte layer obtains a cover of $100 \%$ in most rim and rim-pond transition plots (no significant differences between either micro-relief levels, Kruskal Wallis with post-hoc test: $p>0.1$ ) across the whole tree-line transect while the cover in the ponds is lower $(0 \%$ to $73 \%)$ and differs significantly from that of the rim and rim-pond transitions, $\mathrm{p}<0.01)$. The bryophyte layer is strongly dominated by Bryopsida while Sphagnopsida only occurs in a few plots, mainly on the rim and in the rim-pond transition at $<5 \%$. Only on the rim of the open forest site $(06 / \mathrm{P})$ is average Sphagnopsida cover as high as $35 \%$. Liverworts occur in most rim and rim-pond transition plots of the forest-tundra intersection but at low cover. There is no significant difference in bryophyte cover between the vegetation types (Kruskal Wallis with post-hoc test: $\mathrm{p}>0.1$ ). 


\section{4 type}

235 In total, we found 67 vascular plant taxa and 96 bryophyte taxa. Both alpha-diversity analyses (species richness (Table 2) and Shannon Index (Fig. 3a)) of vascular plants for each polygon are highest for the two polygons of Samoylov, whereas the maxima of bryophyte diversity (Fig. 3b) are equally

238 distributed along the tree-line transect. There are no significant differences in species richness or

239 Shannon Index among the vegetation types, either with respect to vascular plants or with respect to 240 bryophytes (Kruskal Wallis with post-hoc test: $\mathrm{p}>0.1$ ).

Table 2: Species richness of both plant groups by micro-relief level.

\begin{tabular}{lcccccccc}
\hline $\begin{array}{l}\text { Plant type } \\
\text { Polygon }\end{array}$ & complete & rim & $\begin{array}{c}\text { Vascular plants } \\
\text { rp- }\end{array}$ & \multicolumn{4}{c}{ Bryophytes } \\
transition & pond & complete & rim & $\begin{array}{c}\text { rp- } \\
\text { transition }\end{array}$ & pond \\
\hline LP1 & 30 & 29 & 10 & 3 & 39 & 36 & 15 & 5 \\
12/P & 21 & 20 & - & 7 & 25 & 20 & - & 12 \\
P3/III & 10 & 7 & 8 & 3 & 38 & 13 & 34 & 2 \\
P3/II & 11 & 11 & 2 & - & 31 & 29 & 11 & - \\
P3/I & 14 & 14 & 12 & 7 & 40 & 29 & 31 & 15 \\
17/P & 12 & 12 & 12 & 10 & 25 & 19 & 20 & 16 \\
06/P & 15 & - & 15 & 2 & 30 & - & 30 & 4 \\
\hline
\end{tabular}

Within the individual polygons, Shannon index and species richness of vascular plants are often highest on the rims and differ significantly from the rim-pond transitions (Kruskal Wallis with post-

244 hoc test: $\mathrm{p}<0.1)$ and especially from the ponds $(\mathrm{p}<0.001)$, where diversity is almost zero. For example, the Samoylov polygon LP2 has the highest Shannon Index value for vascular plants on the rim with 2.39 , and in the transition it is 1.45 , but only 0.03 in the pond plots where Carex species are the only common vascular plants.

248 In contrast, the Shannon Index of bryophytes is greatest in the rim-pond transition (2.1 in P3/I) and is still high in the pond (0.91 in LP2) compared with the vascular plant layer, but the multiple

250 comparisons of alpha-diversity between the several micro-relief levels show no difference between the

251 rim and the rim-pond transition. Species diversity between the rim-pond and the rim-pond transition to 252 pond, however, are highly significantly different (Kruskal Wallis with post-hoc test: $\mathrm{p}>0.001$ ) from 253 each other. 


\section{Vegetation composition and its relationship with micro-relief and vegetation type}

255

256

257

258

259

260

261

262

263

264

265

266

267

268

269

270

271

272

273

274

275

276

277

278

279

The arrangement of individual plots along the first NMDS axis generally traces the micro-relief both for vascular plants (see Fig. 4a, stress $=0.13$ ) and bryophytes (Fig. 4b, stress $=0.15$ ). Likewise the second NMDS axis separates the vegetation types. The included dummy variables for micro-relief level (rim, rim-pond transition, pond) and vegetation type (open forest, forest-tundra intersection, tundra) mostly yield a significant relationship with the NMDS axes.

The vascular plant species are not evenly distributed in the NMDS plot (Fig. 4a). While most taxa are located in the left part of the plot, i.e. related to the rim (among them shrubs such as Vaccinium vitisidaea, V. uliginosum, Ledum palustre, Salix spp. and herbs such as Saxifraga tenuis, Poa spp., Caryophyllaceae and Fabaceae), only few taxa (among them Comarum palustre, Carex spp., Eriophorum spp., Menyanthes trifoliata, and Epilobium sp.) are characteristic of rim-pond transition plots and pond plots. Shrub taxa such as Vaccinium oxycoccus, V. vitis-idaea, Ledum palustre and Rubus chamaemorus are located in the lower section of the ordination plot reflecting their high abundance in open forests. Generally the separation among the three vegetation types is more obvious for vascular plant ordination, whereas it is less well-defined (and for the tree line not significant) in the bryophyte ordination. Results from variance partitioning generally support the NMDS results. Variables for micro-relief level and vegetation type significantly explain the vascular plant and bryophyte composition of polygons without having overlapping effects (residuals: 0.75); however, explained variance for distance to the nearest water-body calculated by variance partitioning in RDA does not exceed $7.8 \%$ for vascular plants and $5.7 \%$ for bryophytes. Vegetation type explains the compositional turnover better than micro-relief for vascular plants (micro-relief: $7.8 \%$, vegetation type: $13.2 \%$ ), whereas bryophytes show a reversed result (micro-relief: $15.2 \%$, vegetation type: $8.6 \%$ ).

In contrast to vascular plants, bryophytes are more evenly distributed in the NMDS plot although more taxa are characteristic of rim vegetation (Hylocomium splendens, Pleurozium schreberi, Ptilium crista-castrensis, and Climacium dendroides) than pond vegetation (mainly Scorpidium and Calliergon taxa). Meesia triquetra has an intermediate position. Bryophyte taxa such as Calliergon 
280 giganteum, Meesia triquetra, and Climacium dendroides are found mainly in the tundra sites, whereas

281 Calliergon stramineum and Drepanocladus spp. are restricted to the open forest sites.

282 Indicator taxa analyses (Table A1; Table A2) of vascular plants suggest that many taxa are 283 indicative of tundra (Fig. 5). In contrast, many bryophyte taxa are indicative of the forest-tundra 284 intersection. Typical micro-relief indicators (Fig. 6) for the pond sites are Calliergon giganteum and 285 Menyanthes trifoliata. Three bryophyte species (Aneura pinguis, Calliergon trifarium, 286 Sarmenthypnum sarmentosum) are indicative of the rim-pond transition. No vascular plant is 287 indicative of the rim-pond transition. The majority of indicator species of rims are vascular plants (20 288 species), in contrast to only six bryophyte species. 


\section{Patterns of cover, alpha-diversity and compositional turnover of vascular plants and} bryophytes along the micro-relief transect (local scale)

Our investigations demonstrate that vegetation cover, alpha-diversity, and composition change significantly at the micro-relief level within polygons, while changes along the regional vegetation transect are not as clear. Additionally, compositional turnover is stronger between the pond and rimpond transition compared to the rim-pond-transition. The low correlation between polygonal vegetation and regional vegetation might originate from the low number of sampled polygons and the overall strong heterogeneity.

Generally only few individuals of Larix gmelinii trees inhabit the polygon rims. Their rare occurrence may be due to inhibition of their vertical and lateral root system development (Kajimoto et al. 2007) and the low probability of survival due to the permanently water-logged soils (Nikolov and Helmisaari (1992) cited by Kullman (1998)). Compared to the tree layer pattern the shrub and herb layer is better able to indicate the individual micro-relief levels within the polygons. Shrub cover is highest on the rims mostly and shrubs rarely occur in the ponds. This supports the conclusions of Aleksandrova (1980) that dwarf shrubs in tundra grow better on well-drained sites than in water-logged depressions.

The Poales recorded include Carex spp., Eriophorum spp., and Poa spp., which span a wide range of moisture preferences (Jäger 2005). Poales cover varies strongly among plots but does not show a clear trend at micro-relief level, which corresponds with the general preferences of Cyperaceae for wet habitats. Herbs are rare; only Comarum palustre occurs frequently and prefers the rim-pond transition sites, as was observed by de Klerk et al. (2009) in polygons in the Chersky area near the lower Kolyma River. The inference of Menyanthes trifoliata as an indicator for ponds needs to be treated with caution, for although it was recorded in the centre of a polygon, it was, however, growing on a bryophyte mat. Its occurrence on swamp mats was also noted by Walters et al. (1998).

The characteristics of bryophytes (poikilohydric and drought tolerant) makes them rather

314 indifferent to frost and heat damage, and thus tolerable of arctic environmental conditions 315 (Wielgolaski et al. 1981). At drier sites like the rims it may be of advantage that they have a short lag- 
time when changing from desiccation to a productive state when moistened (Proctor 1982; Frahm 2001). Furthermore, they can start photosynthesising under low temperature and light conditions, partially even under a thin layer of snow or ice. Soil moisture is not considered to be an important variable for bryophyte presence, because the rhizoids are merely used for ground fixation (Schofield 1985). Their high cover in comparison to vascular plants, particularly in the rim-pond transition and pond plots, illustrates this advantage (Matveyeva, 1994; Minke et al., 2007). The slightly lower cover and diversity of bryophytes on some rims in comparison to the rim-pond transition may result from their low competitive ability for space and light in comparison to vascular plants (Frahm 2001). typical taxa of wet locations are intermixed. The ponds of polygons are dominated by one to three floating or submerged species of Amblystegiaceae. The dominance of Amblystegiaceae agrees with other studies in the Russian Arctic (de Klerk et al., 2009, Minke et al., 2009). They are characteristic species of rich fens with a slightly acidic to alkaline $\mathrm{pH}(>5.5)$ and abundant in arctic regions (Nebel and Philippi, 2000). Like vascular plants, bryophytes show a complete turnover from rim to pond sites. Liverworts often grow among other species on the rim, but in exclusive patches in rim-pond transition plots.

\section{Patterns of cover, alpha-diversity and compositional turnover of vascular plants and} bryophytes along the regional-scale tree-line transect

A marked compositional turnover of vascular plant and bryophyte abundances across the investigated tree-line transect is indicated by the arrangement of sites in the NMDS that corresponds fairly well with the sequence of vegetation type (Aleksandrova 1980). However, the cover of the local vegetation along the tree-line transect shows no clear pattern. Local vegetation, in accordance with the vegetation type (Matveyeva \& Chernov 2000), shows a decline in the vertical structure of vegetation, i.e. a northward thinning out of tree cover.

Our investigations do not yield a clear trend in shrub cover along the vegetation transect. For example, the highest rim cover of deciduous shrubs is found at P3 in the forest-tundra intersection. P3 is situated near to the Khatanga River that may provide nutrient enrichment as a result of flooding and thus allow 
a more northerly extend for those deciduous shrubs that are known for their low nutrient-use

efficiency (Chapin \& Shaver 1989). Chernov and Matveyeva (1997) point out that vascular plant cover decreases from $50-80 \%$ in the forest-tundra intersection to $5-50 \%$ in the northern subarctic tundra, which fits with our finding that all rims in the forest and forest-tundra intersection have vascular plant cover $>50 \%$ and all tundra sites $<50 \%$. Herbs maintain relatively low cover at rim sites in the open forest polygon, which may reflect their low competitiveness for light and nutrients compared to the taller and deeper rooting shrubs (Swank \& Oechel 1991).

All shrubs that we recorded on polygonal rims represent common elements in the prevailing vegetation type of the respective polygon location (Matveyeva 1994; Matveyeva \& Chernov 2000). In particular, Ericaceae and Rubus chamaemorus are common taxa of subarctic tundra vegetation of the Taymyr peninsula (Matveyeva 1994; Matveyeva \& Chernov 2000). Generally our investigation shows that the vegetation composition of shrubs and herbs of polygonal rims reflects well the regional vegetation composition.

Vascular plant alpha-diversity (species richness and Shannon Index) of the individual polygon plots shows no trends along the tree-line transect, which contradicts the known global trend of decreasing diversity with increasing latitude (Rosenzweig 1995) and also does not match alphadiversity trends described from zonal vegetation studies across the boreal tree line in Siberia (Chernov \& Matveyeva 1997; Matveyeva \& Chernov 2000). Highest herb alpha-diversity is found at Samoylov Island in the Lena River delta and in the polygons (P3) near the Khatanga River. This likely originates from the corridor function of large rivers for southern taxa (Matveyeva \& Chernov 2000), which additionally causes a more temperate climate. Furthermore, the high herb diversity at our tundra sites may portray the regional diversity centre of Saxifragaceae and Brassicaceae that has previously been described for the northern subarctic tundra, comparable to taxa of Rosaceae and Fabaceae for the typical tundra (Matveyeva \& Chernov 2000). All families are represented by several species in the polygon plots.

Bryophyte cover is high at all sites and seems not to be affected by latitude, which fits with the findings of Matveyeva and Chernov (2000) who describe a reduction of bryophyte cover along a transect across the Taymyr Peninsula only at the transition from northern tundra to polar desert. The 
high number of bryophyte taxa in the polygon plots illustrates the high diversity that even exceeds vascular plant diversity. Our findings are in line with the high bryophyte taxa numbers documented by the floristic studies of Fedosov and Ignatova (2005) who found 233 species at Ledyanaya Bay (Taymyr Peninsula), of Fedosov (2008) who counted 130 species on the Longdoko Massif, and of Fedosov et al. (2011) who described 520 taxa for the Anabar Plateau. Furthermore, bryophytes of the arctic are highly diverse at the species level often due to a fixation of ecotype adaption as genetic heterogeneity (McGraw 1995). We do not observe an alpha-diversity trend along the tree-line transect, and no study exists that show a trend in moss diversity across the Russian boreal tree line (Mutke \& Barthlott 2005), plus Shaw et al. (2005) show that the latitudinal gradient in bryophyte diversity is weak. In our plots, we do find a marked taxa turnover as indicated by NMDS. Drepanocladus spp. (including Warnstorfia spp.), for example, is common in the pond of the forest site while Scorpidium scorpioides and Calliergon giganteum communities dominate the ponds from the tree line to more northerly sites. Furthermore, Meesia triquetra was first observed in the forest-tundra intersection and its cover increases farther north which aligns with its identification as a glacial relict (Nebel \& Philippi 2005).

\section{Indicator potential of vascular plant and bryophyte remains from polygonal peats for}

\section{the reconstruction of local hydrological and regional vegetation changes}

Polygonal sediments are frequently used for the reconstruction of past arctic environments and climates. Commonly pollen (de Klerk et al. 2009; Minke et al. 2009) and vascular plant macrofossil analyses (Birks 2001, Kienast et al. 2001) are applied but identified moss remains are also used for reconstruction (Zibulski et al. 2013). Investigations of sub-fossil assemblages reveal that preserved remains mainly originate from the local vegetation (Birks 2001) even for pollen in polygonal structures (de Klerk et al. 2011).

The high vegetation turnover at the local scale, and thus changes in the polygon morphology over time, will result in a marked vegetation change that does not necessarily reflect changes in the vegetation type or climate but rather traces variations in the local hydrological conditions. The separate interpretation of qualitative changes of preserved rim taxa, in particular of leaves of shrubs 
(for example Dryas, Vaccinium, and Ledum) and herbs, will allow the reconstruction of vegetationtype changes. Our results indicate that the absence of Larix macrofossils in polygonal sediments does not reliably indicate a position beyond the tree-line. Generally, the deposition of allochthonous material from sites further south need to be taken into account in palaeoecological studies using sediments from polygons located near to rivers due to frequent flooding (Zibulski et al., 2013).

Among the bryophyte taxa, Hylocomium splendens, Climacium dendroides and Pleurozium schreberi are of potential use for the indication of dry rim sites. The high number of inferred moss indicators for tracing micro-relief conditions indicates that bryophyte remains from polygonal sediments-in particular from the rim-pond transition - are useful for tracing changes of the water-level. Useful indicators of the water-level are Sarmenthypnum sarmentosum and Calliergon trifarium that are easy to determine and are thus suitable for palaeo-investigations (Jakab \& Sümegi 2011). Liverworts such as Aneura pinguis are not commonly usable for palaeo-investigations, because they are poorly preserved in sediments (Janssens 1988). Remains of Calliergon richardsonii are sometimes difficult to separate from Calliergon giganteum. Easily identifiable bryophytes are Tomentypnum nitens, Aulacomnium turgidum and A. palustre for drier rim-pond transition sites. In addition, a high abundance of Meesia triquetra is a reliable distinguishing feature to separate wet rim-pond transition

414 from pond sites. Our study reveals no vascular plant taxon as a suitable indicator for the rim-pond transition.

Using deep-pond sediments for environmental reconstructions has the advantage that sedimentation rates are mostly higher than at the rim or rim-pond transition and preservation conditions are better. However, there are several risks. First, the fossil record has low diversity or is even absent and thus not responsive to slight environmental changes. Second, some submersed living Amblystegiaceae can have very long shoots which complicates the stratigraphical interpretation. For example, Calliergon giganteum plants in LP1 had a length of around $60 \mathrm{~cm}$, suggesting a high annual growth rate of $10 \mathrm{~mm} \mathrm{year}^{-1}$, as also inferred for Canadian lakes (Sand-Jensen et al. 1999). Accordingly, even though bryophyte remains are autochthonous, they are not necessarily in the correct stratigraphical context (Birks 1982). Third, the close association between submerged brown mosses and methanotrophic bacteria leads to an uptake of old carbon from bacterial methane oxidation 
products into the biomass of mosses (Liebner et al. 2011), which affects dating results. It is recommended to date terrestrial mosses rather than submerged species.

\section{Implications of vegetation changes for future Arctic warming and conclusions}

Taking the spatial patterns of cover, diversity, and composition as a guideline, the following implications can be drawn for future changes in the Siberian lowlands characterized by polygonal landscapes.

Vascular plant cover decreases from the southern open forest to the northern subarctic tundra, whereas the cover of bryophytes is less affected by the latitudinal gradient. Cover of both plant groups decreases from the rim to pond, but bryophytes still occur at reasonably high abundance in shallow ponds. Bryophytes at northern sites in particular, strongly contribute or even dominate plant cover (and probably also standing biomass) and, because of low decomposition rates in the ponds, also dominate buried organic material in arctic regions and thus contribute to carbon storage. The low nitrogen and phosphorus content of bryophyte remains (Aerts et al. 1999) and the high content of phenolic and non-polar cell compounds slows decomposition by micro-organisms and fungi (Turetsky 2003), which leads to high organic matter accumulation in arctic landscapes. Furthermore, thick mats of bryophytes isolate the soil against thermal radiation resulting in a high permafrost table and water saturation of the soil (Woo \& Young 2006). The low soil temperatures inhibit the germination of seeds or shorten the development phase for vascular plants.

The alpha-diversity patterns differ between vascular plants and bryophytes. The increasing Shannon Index of vascular plants from the open forest to the tundra suggest the known dispersal along river corridors, while the unclear trend for bryophytes show that the tree line is not the threshold for directional patterns in bryophyte composition (Matveyeva \& Chernov 2000). A strong decrease in alpha-diversity is revealed for vascular plants from rim to pond while bryophytes show highest diversity at the rim-pond transition mostly. Higher temperatures in the future will probably cause greater cover of vascular plants on the rims, in particularly for shrubs (Pajunen et al. 2011; MyersSmith et al. 2011). This increasing competitive pressure associated with lower water-levels could leads to a decreasing carbon sink and permafrost-isolation function of bryophytes (Billings et al. 1982). 
However, the negative effect of shrub expansion in tundra ecosystems, which leads to a decrease in the

454

455

456

457

458

459

460

461

462

463

464

465

466

467

468

469

470

471

472

473

474

475

476

477

478

479

480

481

cover and diversity of bryophytes (Pajunen et al. 2011), cannot be underpinned by the calculated bryophyte cover and diversity parameter, whereas the cover of herbs is lower, if shrubs are abundant on the rim.

Our analyses reveal a turnover in community composition along the vegetation-type gradient from open forest to tundra. However, this latitudinal gradient is less pronounced in the bryophyte composition. In contrast, bryophytes show a strong taxa turnover along the micro-relief gradient within each polygon, while vascular plants are almost absent from the rim-pond transition and pond sites. Accordingly, future compositional changes of polygonal vegetation will strongly depend on the regional (increase of soil wetness by thawing permafrost) and local (change in drainage conditions) climatic expression of global warming. On the landscape scale new taxa-combinations and taxareshuffling will probably appear because vascular plants and bryophytes on the rim and in the pond react in different ways. For example, future changes of a polygon may rather depend on changes in local water conditions than on changes in air temperature, although these can affect the local water conditions.

\section{Acknowledgements}

We thank M. Wieczorek and J. Klemm for assistance in the field and Dierk Michaelis for the confirmation of Sphagnum rubellum.

\section{References}

Aerts, R., Verhoeven, J.T.A. \& Whigham, D.F. 1999. Plant-mediated controls on nutrient cycling in temperate fens and bogs. Ecology 80: 2170-2181.

Aleksandrova, V.D. 1980. The Arctic and Antarctic: Their Division into Geobotanical Areas. (Komarov lectures; 29). Fakenham Press Limited, Norfolk.

Benjamini, Y., \& Hochberg, Y. 1995. Controlling the false discovery rate: a practical and powerful approach to multiple testing. Journal of the Royal Statistical Society. Series B (Methodological) 57: 289-300.

Betts, R.A. 2000. Offset of the potential carbon sink from boreal forestation by decreases in surface albedo. Nature 408: 187-190. 
Billings, W.D., Luken, J.O., Mortensen, D.A., \& Peterson, K.M. 1982. Arctic tundra: A source or sink for atmospheric carbon dioxide in a changing environment? Oecologia 53: 7-11.

Birks, H.H. 2001. Plant macrofossils. In: Smol, J.P., Birks, H.J.B. \& Last, W.M. (eds.), Tracking Environmental Change Using Lake Sediments, vol. 3: Terrestrial, Algal and Siliceous Indicators, pp. 49-74. Kluwer Academic Publishers, Dordrecht.

Birks, H.J.B. 1982. Quaternary Bryophyte Palaeoecology. In: Smith, A.J.E. (ed.), Bryophyte Ecology, pp. 473-490. Springer Netherlands.

Boike, J., Kattenstroth, B., Abramova, K., Bornemann, N., Chetverova, A., Fedorova, I., Fröb, K., Grigoriev, M., Grüber, M., Kutzbach, L., Langer, M., Minke, M., Muster, S., Piel, K., Pfeiffer, E.-M., Stoof, G., Westermann, S., Wischnewski, K., Wille, C. \& Hubberten, H.-W. 2013. Baseline characteristics of climate, permafrost and land cover from a new permafrost observatory in the Lena River Delta, Siberia (1998-2011). Biogeosciences 10: 2105-2128.

Bonan, G.B., Pollard, D. \& Thompson, S.L. 1992. Effects of boreal forest vegetation on global climate. Nature 359: 716-718.

Borcard, D., Legendre, P. \& Drapeau, P. 1992. Partialling out the spatial component of ecological variation. Ecology 73: 1045-1055.

Botch, M.S., Kobak, K.I., Vinson, T.S., \& Kolchugina, T.P. 1995. Carbon pools and accumulation in peatlands of the former Soviet Union. Global Biogeochemical Cycles 9: 37-46.

Braun-Blanquet, J. 1964. Pflanzensoziologie: Grundzüge der Vegetationskunde. Springer, Vienna.

Callaghan, T.V., Björn, L.O., Chernov, Y., Chapin, T., Christensen, T.R., Huntley, B., Ims, R.A., Johansson, M., Jolly, D., Jonasson, S., Matveyeva, N., Panikov, N., Oechel, W., Shaver, G., Elster, J., Henttonen, H., Laine, K., Taulavuori, K., Taulavuori, E. \& Zöckler, C. 2004. Biodiversity, distributions and adaptations of Arctic species in the context of environmental change. Ambio 33: 404-417.

Chapin III, F.S. \& Shaver, G.R. 1989. Differences in growth and nutrient use among Arctic plant growth forms. Functional Ecology 3: 73-80.

Chernov, Y.I. \& Matveyeva, N.V. 1997. Arctic ecosystems in Russia. In: Goodall, D.W. (ed.), Ecosystems of the World, pp. 361-507.Elsevier, Amsterdam.

De Cáceres, M.D., \& Jansen, F. 2013. indicspecies: Studying the statistical relationship between species and groups of sites. http://cran.r-project.org/web/packages/indicspecies/index.html

De Cáceres, M.D., \& Legendre, P. 2009. Associations between species and groups of sites: indices and statistical inference. Ecology 90: 3566-3574.

de Klerk, P., Donner, N., Joosten, H., Karpov, N.S., Minke, M., Seifert, N. \& Theuerkauf, M. 2009. Vegetation patterns, recent pollen deposition and distribution of non-pollen palynomorphs in a polygon mire near Chokurdakh (NE Yakutia, NE Siberia). Boreas 38: 39-58.

de Klerk, P., Donner, N., Karpov, N.S., Minke, M. \& Joosten, H. 2011. Short-term dynamics of a lowcentred ice-wedge polygon near Chokurdakh (NE Yakutia, NE Siberia) and climate change during the last ca 1250 years. Quaternary Science Reviews 30: 3013-3031.

de Mendiburu, F. 2014. agricolae: Statistical Procedures for Agricultural Research. http://cran.rproject.org/web/packages/agricolae/index.html 
Fedosov, V.E. 2008. Moss flora of intrusive massive Longdoko. Электронный журнал" Исследовано в России 11: 229-235. [In Russian]

Fedosov, V.E. \& Ignatova, E.A. 2005. Bryophyte flora of the "Ledyanaya Bay" key plot (Byrranga Range, Taimyr, Siberian Arctic). Arctoa 14: 71-94.

Fedosov, V.E., Ignatova, E.A., Ignatov, M.S. \& Maksimov, A.I. 2011. Rare species and preliminary list of mosses of the Anabar plateau (subarctic Siberia). Arctoa 20: 153-174.

Foley, J.A., Kutzbach, J.E., Coe, M.T. \& Levis, S. 1994. Feedbacks between climate and boreal forests during the Holocene epoch. Nature 371: 52-54.

Frahm, J.P. 2001. Biologie der Moose. Spektrum Akademischer Verlag.

Frahm, J.P. 2011. Kommentierte Liste der Laubmoose Deutschlands. Archive for Bryology 79: 1-51.

Frahm, J.-P. \& Frey, W. 2004. Moosflora. UTB, Stuttgart.

French, H.M. 2007. The Periglacial Environment. John Wiley and Sons.

Gordeev, V. \& Shevchenko, V.P. 1995. Chemical composition of suspended sediments in the Lena River and its mixing zone. Reports on Polar Research 154-169.

Grosse, G., Schirrmeister, L. \& Malthus, T.J. 2006. Application of Landsat-7 satellite data and a DEM for the quantification of thermokarst-affected terrain types in the periglacial Lena-Anabar coastal lowland. Polar Research 25: 51-67.

Jakab, G., \& Sümegi, P. 2011. The role of bryophyte paleoecology in Quaternary climate reconstructions. In: Tuba, Z., Slack, N.G. \& Stark, L.R. (eds.), Bryophyte Ecology and Climate Change, pp. 335-358. Cambridge University Press, Cambridge.

Jäger, E.J. 2005. Rothmaler - Exkursionsflora von Deutschland. Bd. 2: Gefäßpflanzen: Grundband. Spektrum Akademischer Verlag.

Janssens, J.A. 1988. Fossil bryophytes and paleoenvironmental reconstruction of peatlands. In: Methods in Bryology. Proceedings of the Bryological Methods Workshop, Mainz, pp. 299306.

Kajimoto, T., Osawa, A., Matsuura, Y., Abaimov, A.P., Zyryanova, O.A., Kondo, K., Tokuchi, N. \& Hirobe, M. 2007. Individual-based measurement and analysis of root system development: case studies for Larix gmelinii trees growing on the permafrost region in Siberia. Journal of Forest Research 12: 103-112.

Kharuk, V.I., Ranson, K.J., Im, S.T. \& Naurzbaev, M.M. 2006. Forest-tundra larch forests and climatic trends. Russian Journal of Ecology 37: 291-298.

Kienast, F., Siegert, C., Dereviagin, A. \& Mai, D.H. 2001. Climatic implications of Late Quaternary plant macrofossil assemblages from the Taymyr Peninsula, Siberia. Global and Planetary Change 31: 265-281.

Kullman, L. 1998. Palaeoecological, biogeographical and palaeoclimatological implications of early Holocene immigration of Larix sibirica Ledeb. into the Scandes Mountains, Sweden. Global Ecology and Biogeography Letters 7: 181-188.

Kutzbach, L., Wagner, D. \& Pfeiffer, E.M. 2004. Effect of microrelief and vegetation on methane emission from wet polygonal tundra, Lena Delta, Northern Siberia. Biogeochemistry 69: 341362. 
Legendre, P. 2008. Studying beta diversity: ecological variation partitioning by multiple regression and canonical analysis. Journal of Plant Ecology 1: 3-8.

Legendre, P., \& Gallagher, E.D. 2001. Ecologically meaningful transformations for ordination of species data. Oecologia 129: 271-280.

Liebner, S., Zeyer, J., Wagner, D., Schubert, C., Pfeiffer, E.-M. \& Knoblauch, C. 2011. Methane oxidation associated with submerged brown mosses reduces methane emissions from Siberian polygonal tundra. Journal of Ecology 99: 914-922.

Lobin, W., Fischer, E., Frahm, J.-P., Frey, W. \& Gams, H. 1995. Kleine Kryptogamenflora, Bd.4, Die Moospflanzen und Farnpflanzen Europas. Spektrum Akademischer Verlag.

MacDonald, G.M., Velichko, A.A., Kremenetski, C.V., Borisova, O.K., Goleva, A.A., Andreev, A.A., Cwynar, L.C., Riding, R.T., Forman, S.L., Edwards, T.W.D., Aravena, R., Hammarlund, D., Szeicz, J.M. \& Gattaulin, V.N. 2000. Holocene treeline history and climate change across northern Eurasia. Quaternary Research 53: 302-311.

Matveev, I.A. (ed.). 1989. Agricultural Atlas of the Republic Sakha (Yakutia). Nauka, Moscow.

Matveyeva, N.V. 1994. Floristic classification and ecology of tundra vegetation of the Taymyr Peninsula, northern Siberia. Journal of Vegetation Science 5: 813-828.

Matveyeva, N. \& Chernov, Y. 2000. Biodiversity of terrestrial ecosystems. In: Nuttall, M. \& Callaghan, T. (eds), The Arctic: environment, people, policy, pp 233-273. CRC Press

McGraw, J.B. 1995. Patterns and causes of genetic diversity in Arctic plants. In Chapin, F.S. \& Körner, C. (eds.), Arctic and Alpine Biodiversity: Patterns, Causes and Ecosystem Consequences, pp. 33-43. Springer, Berlin.

Minke, M., Donner, N., Karpov, N., de Klerk, P. \& Joosten, H. 2009. Patterns in vegetation composition, surface height and thaw depth in polygon mires in the Yakutian Arctic (NE Siberia): a microtopographical characterisation of the active layer. Permafrost and Periglacial Processes 20: 357-368.

Minke, M., Donner, N., Karpov, N.S., de Klerk, P. \& Joosten, H. 2007. Distribution, diversity, development and dynamics of polygon mires: examples from Northeast Yakutia (Siberia). Peatlands International 1/2007: 36-40.

Mutke, J. \& Barthlott, W. 2005. Patterns of vascular plant diversity at continental to global scales. Biologiske Skrifter 55: 521-531.

Myers-Smith, I.H., Forbes, B.C., Wilmking, M., Hallinger, M., Lantz, T., Blok, D., Tape, K.D., Macias-Fauria, M., Sass-Klaassen, U., Lévesque, E., Boudreau, S., Ropars, P., Hermanutz, L., Trant, A., Collier, L.S., Weijers, S., Rozema, J., Rayback, S.A., Schmidt, N.M., SchaepmanStrub, G., Wipf, S., Rixen, C., Ménard, C.B., Venn, S., Goetz, S., Andreu-Hayles, L., Elmendorf, S., Ravolainen, V., Welker, J., Grogan, P., Epstein, H.E., \& Hik, D.S. 2011. Shrub expansion in tundra ecosystems: dynamics, impacts and research priorities. Environmental Research Letters 6: 045509.

Nebel, M. \& Philippi, G. 2005. Die Moose Baden-Württembergs. Ulmer, Stuttgart.

Nikolov, N. \& Helmisaari, H. 1992. Silvics of the circumpolar boreal forest tree species. In: Shugart, H.H., Leemans, R. \& Bonan, G.B. (eds) A Systems Analysis of the Global Boreal Forest, pp. 13-84. Cambridge University Press, Cambridge. [In Swedish] 
Oechel, W.C., Hastings, S.J., Vourlrtis, G., Jenkins, M., Riechers, G. \& Grulke, N. 1993. Recent change of Arctic tundra ecosystems from a net carbon dioxide sink to a source. Nature 361: $520-523$.

Oksanen, J. 2011. Multivariate analysis of ecological communities in R: vegan tutorial. $R$ package version

Oksanen, J., Blanchet, F.G., Kindt, R., Legendre, P., Minchen, P.E., O’Hara, B., Simpson, G.L., Solymos, P., Stevens, M.H.H. \& Wagner, H. 2013. vegan: Community ecology package. http://cran.r-project.org/web/packages/vegan/index.html

Pajunen, A. M., Oksanen, J. \& Virtanen, R. 2011. Impact of shrub canopies on understorey vegetation in western Eurasian tundra. Journal of Vegetation Science 22: 837-846.

Proctor, M.C.F. 1982. Physiological Ecology: Water relations, light and temperature responses, carbon balance. In: Smith, A.J.E. (ed.), Bryophyte Ecology, pp. 333-381. Springer Netherlands.

R Core Team. 2014. R: A Language and Environment for Statistical Computing. R Foundation for Statistical Computing, Vienna, Austria. URL http://www.R-project.org/.

Reichelt, G. \& Wilmanns, O. 1973. Vegetationsgeographie. Georg Westermann Verlag, Braunschweig.

Rivas-Martinez, S. \& Rivas-Saenz, S. 2009. Worldwide Bioclimatic Classification System, 19962009. Phytosciological Research Center, Spain. http://www.globalbioclimatics.org/

Rosenzweig, M.L. 1995. Species Diversity in Space and Time. Cambridge University Press, Cambridge.

Sand-Jensen, K., Riis, T., Markager, S. \& Vincent, W.F. 1999. Slow growth and decomposition of mosses in Arctic lakes. Canadian Journal of Fisheries and Aquatic Sciences 56: 388-393.

Schofield, W.B. 1985. Introduction to Bryology. The Blackburn Press, New Jersey.

Schwamborn, G., Rachold, V. \& Grigoriev, M.N. 2002. Late Quaternary sedimentation history of the Lena Delta. Quaternary International 89: 119-134.

Shaw, A.J., Cox, C.J. \& Goffinet, B. 2005. Global patterns of moss diversity: Taxonomic and molecular inferences. Taxon 54: 337-352.

Smith, L.C., MacDonald, G.M., Velichko, A.A., Beilman, D.W., Borisova, O.K., Frey, K.E., Kremenetski, K.V. \& Sheng, Y. 2004. Siberian peatlands a net carbon sink and global methane source since the early Holocene. Science 303: 353-356.

Sturm, M., Racine, C. \& Tape, K. 2001. Climate change: Increasing shrub abundance in the Arctic. Nature 411: 546-547.

Swank, S.E. \& Oechel, W.C. 1991. Interactions among the effects of herbivory, competition, and resource limitation on Chaparral herbs. Ecology 72: 104-115.

Turetsky, M.R. 2003. The role of bryophytes in carbon and nitrogen cycling. The Bryologist 106: 395409.

Walters, J.C., Racine, C.H. \& Jorgenson, M.T. 1998. Characteristics of permafrost in the Tanana Flats, Interior Alaska. In: Lewkowicz, A.G. \& Allard, M. (eds), Permafrost: Seventh International Conference, June, pp. 23-27. University of Laval, Québec. 
Wielgolaski, F.E., Bliss, L.C., Svoboda, J. \& Doyle, G. 1981. Primary production of tundra. In: Bliss, L.C., Heal, O.W. \& Moore, J.J. (eds), Tundra Ecosystems: A Comparative Analysis, pp. 187226. Cambridge University Press, Cambridge.

Woo, M. \& Young, K.L. 2006. High Arctic wetlands: Their occurrence, hydrological characteristics and sustainability. Journal of Hydrology 320: 432-450.

Zibulski, R., Herzschuh, U., Pestryakova, L.A., Wolter, J., Müller, S., Schilling, N., Wetterich, S., Schirrmeister, L., \& Tian, F. 2013. River flooding as a driver of polygon dynamics: modern vegetation data and a millennial peat record from Anabar River lowlands (Arctic Siberia). Biogeosciences 5703-5728. 


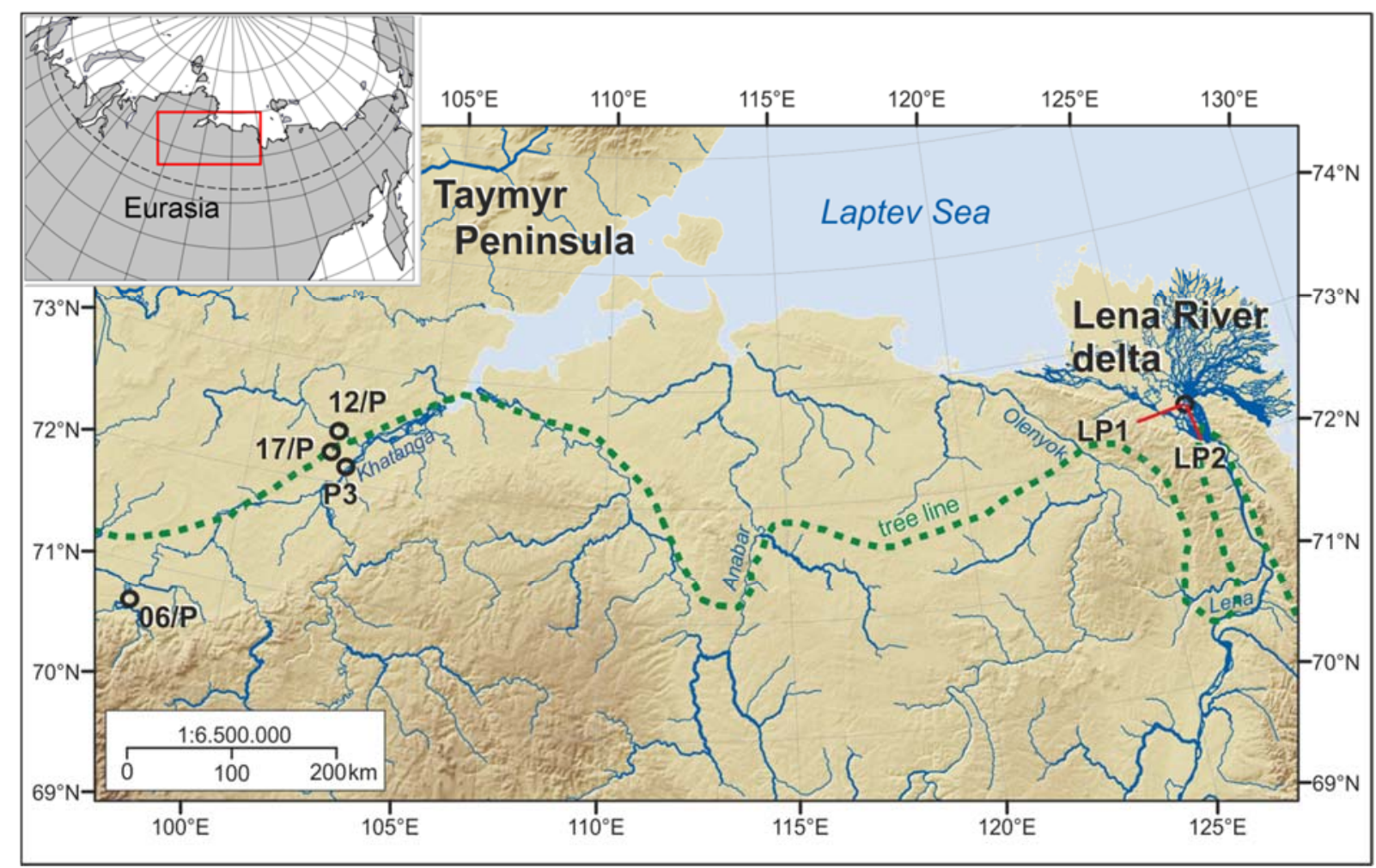

Fig. 1: Map of the two study areas: Khatanga in the south-east of the Taymyr Peninsula and Samoylov Island in the Lena 654 River delta, with the six polygon sites sampled and the current tree line marked (MAP by Th. Böhmer). 


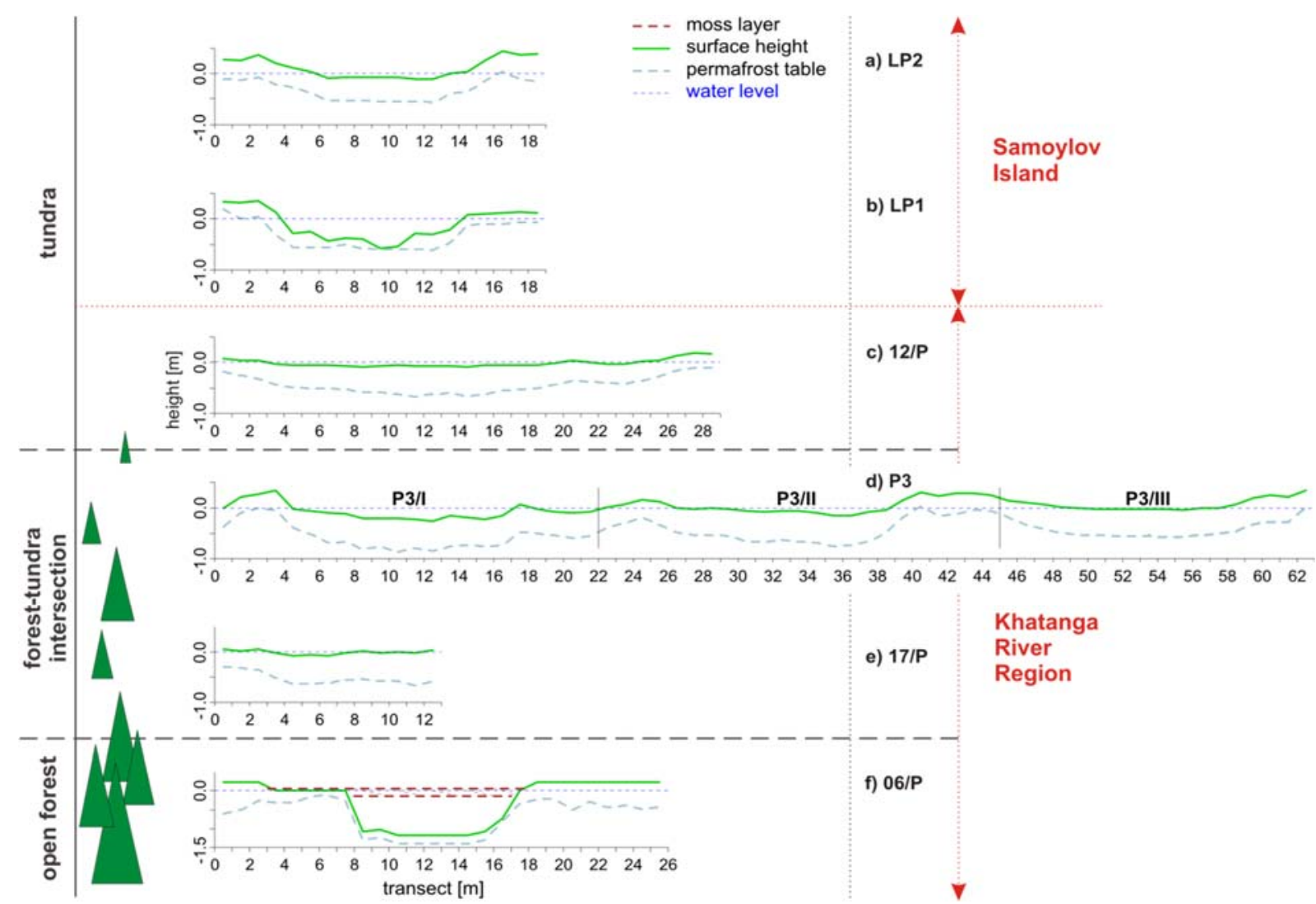

656 Fig. 2: Cross sections of the eight polygons, arranged according to their geographical position from north to south. Two lowcentred polygons $(\mathrm{a}+\mathrm{b})$ were studied on Samoylov Island in the Lena River Delta in the northern subarctic tundra. A further six sites were investigated in the Khatanga Region (c-f). Polygon 12/P (c) is located in a treeless subarctic tundra part. A sequence of three adjacent polygons P3 (d), is situated in a polygon field in the vicinity of the Khatanga River. Polygon 17/P

660 (e) is situated close to the tree line (forest-tundra intersection - forest site). The southernmost Khatanga site 06/P is an open 661 forest site. The length of the cross section transects in metres corresponds to the number of plots. 
a) vascular plants
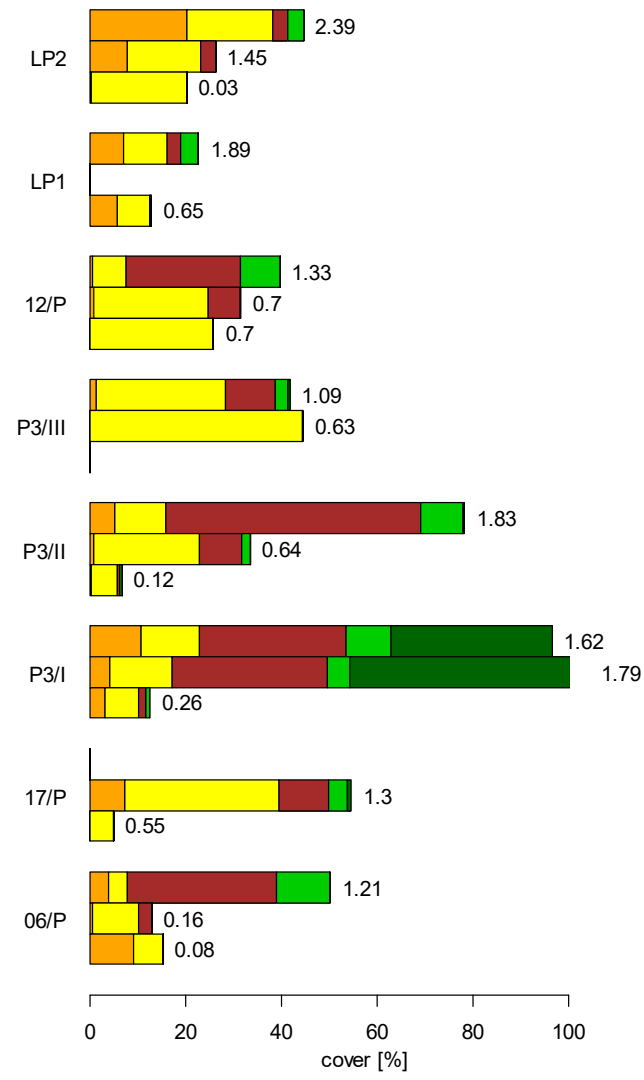

b) bryophytes
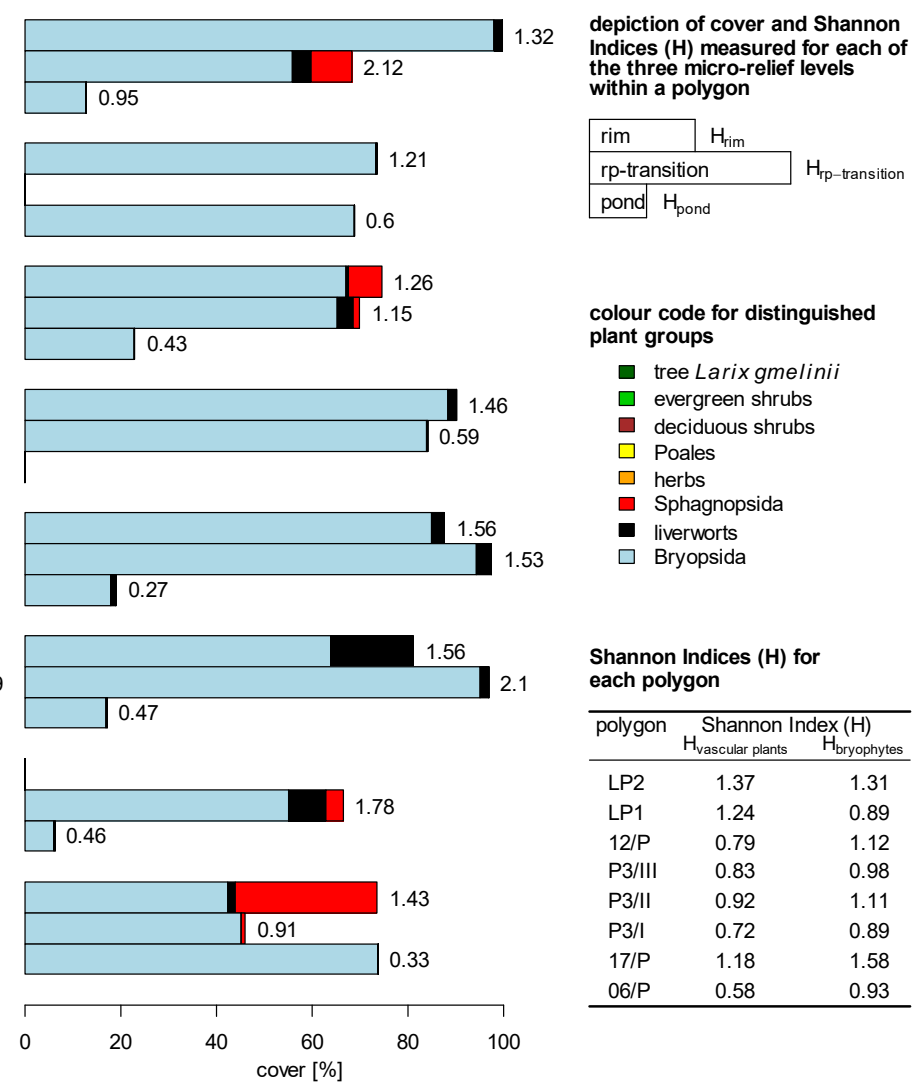

colour code for distinguished plant groups

- tree Larix gmelinii

$\square$ evergreen shrubs

$\square$ deciduous shrubs

$\square$ Poales

$\square$ herbs

- Sphagnopsida

- liverworts

$\square$ Bryopsida

Shannon Indices $(H)$ for each polygon

\begin{tabular}{ccc}
\hline polygon & \multicolumn{2}{c}{ Shannon Index $(\mathrm{H})$} \\
& $\mathrm{H}_{\text {vascular plants }}$ & $\mathrm{H}_{\text {bryophytes }}$ \\
\hline LP2 & 1.37 & 1.31 \\
LP1 & 1.24 & 0.89 \\
12/P & 0.79 & 1.12 \\
P $3 / I I I$ & 0.83 & 0.98 \\
P3/II & 0.92 & 1.11 \\
P $3 / I$ & 0.72 & 0.89 \\
17/P & 1.18 & 1.58 \\
06/P & 0.58 & 0.93 \\
\hline
\end{tabular}

662 Fig. 3: Vegetation cover of all polygons separated into vascular plant layer (a), and bryophyte layer (b). The Shannon Index 663 for the polygon micro-relief levels (rim, rim-pond transition, and pond) is shown beside the columns. The Shannon Index of 664 each layer in the complete polygon is shown at the bottom right. 
a) vascular plants
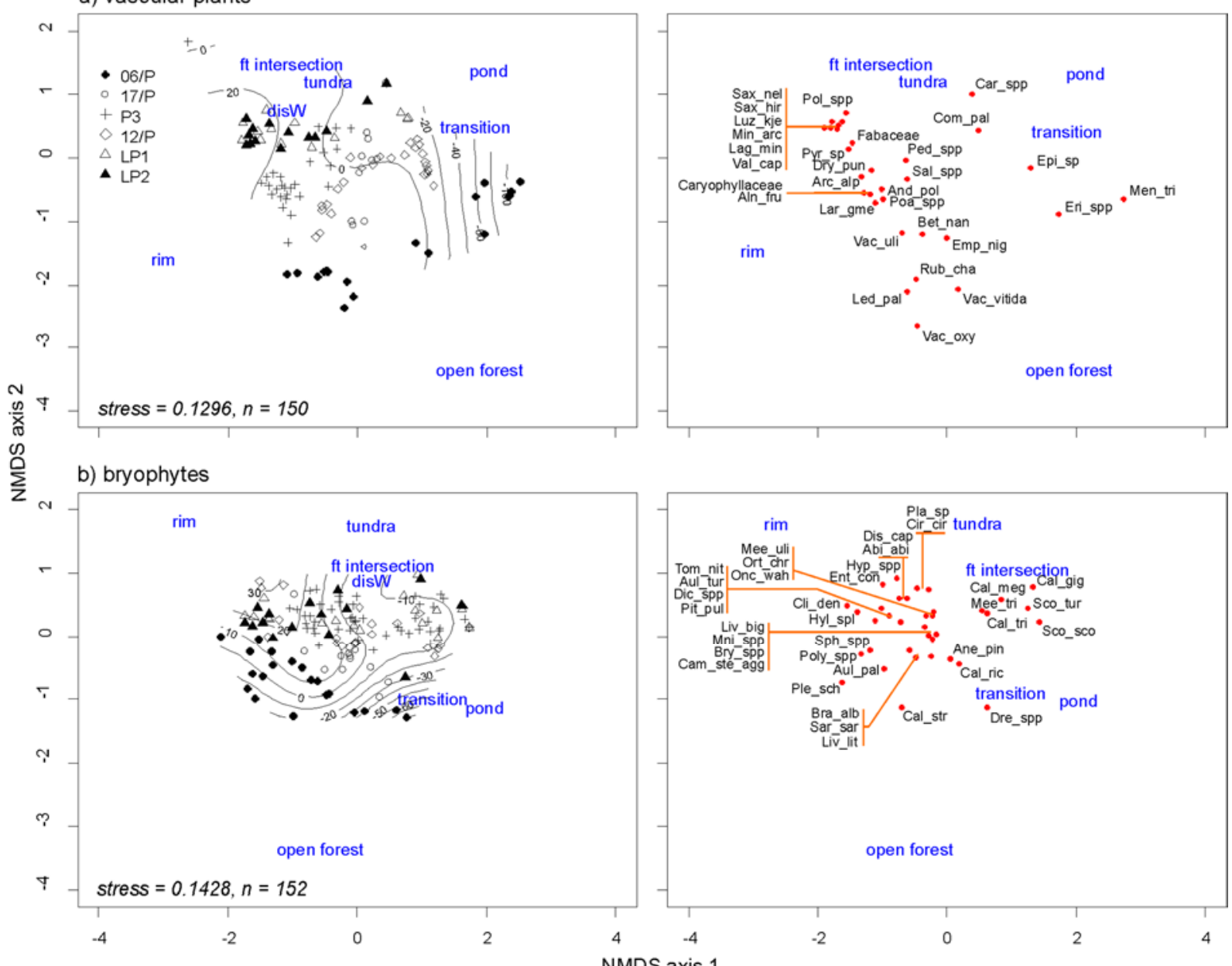

NMDS axis 1

667 Fig. 4: NMDS plots on the left side showing the distribution of sample sites based on a) the vascular plant community and b) the bryophyte community (underlain by plant position at surface height in centimetres) and on the right side the species distribution for both plant groups. The micro-relief level and vegetations types are included as dummy variables. 


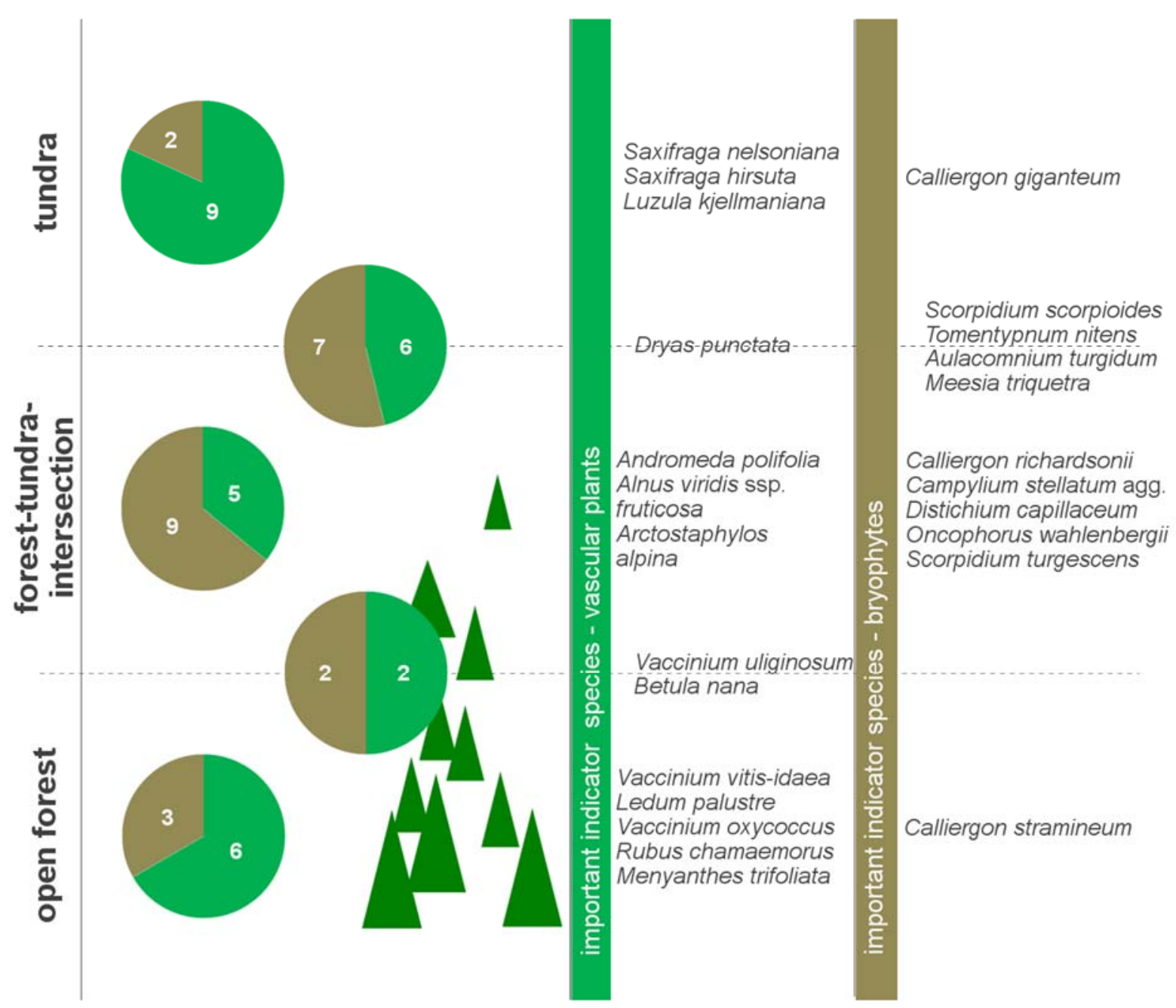

670 Fig. 5: Important indicator species for the latitudinal vegetation gradient (pie charts show the proportion of indicator species

671 for vascular plants (green) and bryophytes (brown)). 


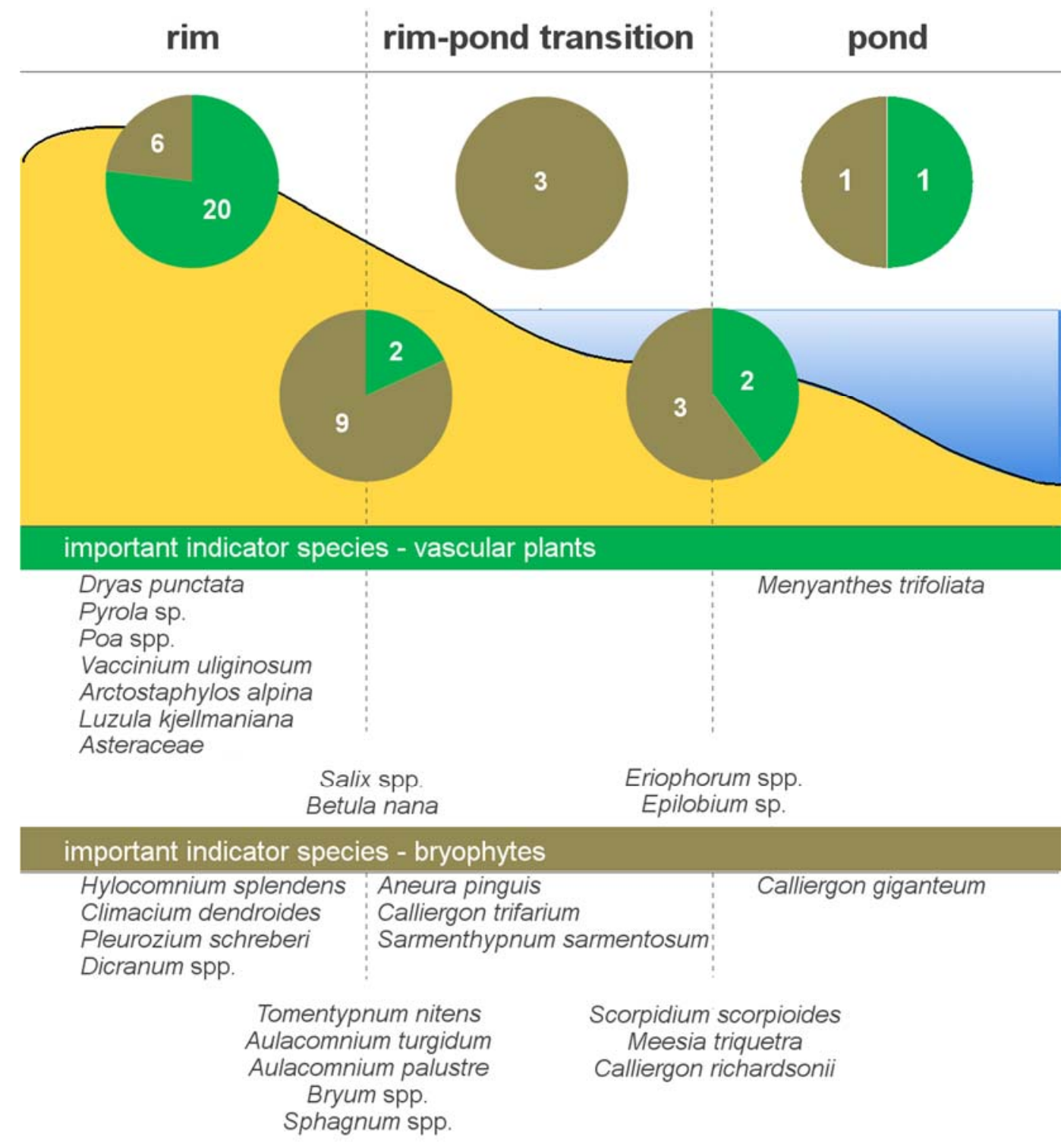

672 Fig. 6: Important indicator species for the different micro-relief levels. Pie charts show the total number of indicator species for vascular plants (green) and bryophytes (brown). 
Table A1: All plant species of the vegetation survey with their suitability as an indicator (significances are marked with asterisks: $* \mathrm{p}<0.05,{ }^{* *} \mathrm{p}<0.01, * * * \mathrm{p}<0.001$ ) and their cover for the micro-relief levels of a polygon.

\begin{tabular}{|c|c|c|c|c|c|c|c|c|c|c|c|}
\hline \multirow[t]{2}{*}{ species } & \multirow[t]{2}{*}{ abbr. } & \multirow{2}{*}{$\begin{array}{l}\text { indicator } \\
\text { micro-relief }\end{array}$} & \multicolumn{3}{|c|}{ rim } & \multicolumn{3}{|c|}{$\begin{array}{c}\text { cover }[\%] \\
\text { rim-pond transition }\end{array}$} & \multicolumn{3}{|c|}{ pond } \\
\hline & & & $\max$ & $\min$ & median & $\max$ & $\min$ & median & $\max$ & $\min$ & median \\
\hline \multicolumn{12}{|l|}{ vascular plants } \\
\hline Alnus viridis spp. fruticosa & Aln_fru & $\operatorname{rim} * *$ & 37.5 & 0 & 0 & 10 & 0 & 0 & 4 & 0 & 0 \\
\hline Andromeda polifolia & And_pol & $\operatorname{rim} * *$ & 4 & 0 & 0 & 4 & 0 & 0 & 4 & 0 & 0 \\
\hline Arctostaphylos alpina & Arc_alp & $\operatorname{rim} * * *$ & 10 & 0 & 0 & 3 & 0 & 0 & 3 & 0 & 0 \\
\hline Asteraceae & Asteraceae & $\operatorname{rim} * * *$ & 3 & 0 & 0 & 0 & 0 & 0 & 0 & 0 & 0 \\
\hline Betula nana & Bet_nan & $\operatorname{rim} / \mathrm{rp}$-transition $* * *$ & 37.5 & 0 & 0.5 & 20 & 0 & 0 & 4 & 0 & 0 \\
\hline Caltha palustris & Cal_pal & - & 0 & 0 & 0 & 0.5 & 0 & 0 & 0.5 & 0 & 0 \\
\hline Carex spp. & Car_spp & - & 37.5 & 0 & 4 & 20 & 0 & 0 & 4 & 0 & 0 \\
\hline Caryophyllaceae & $\begin{array}{l}\text { Caryo- } \\
\text { phyllaceae }\end{array}$ & $\operatorname{rim} * * *$ & 3 & 0 & 0 & 3 & 0 & 0 & 0 & 0 & 0 \\
\hline $\begin{array}{l}\text { Chrysosplenium } \\
\text { alternifolium }\end{array}$ & Chr_alt & - & 3 & 0 & 0 & 0 & 0 & 0 & 0 & 0 & 0 \\
\hline Comarum palustre & Com_pal & - & 10 & 0 & 0 & 10 & 0 & 0 & 10 & 0 & 0 \\
\hline Draba alpina & Dra_alp & rim* & 3 & 0 & 0 & 0 & 0 & 0 & 0 & 0 & 0 \\
\hline Dryas punctata & Dry_pun & $\operatorname{rim} * * *$ & 20 & 0 & 3 & 3 & 0 & 0 & 0 & 0 & 0 \\
\hline Empetrum nigrum & Emp_nig & - & 0 & 0 & 0 & 10 & 0 & 0 & 0 & 0 & 0 \\
\hline Epilobium sp. & Epi_sp & $\begin{array}{c}\text { pond/rp- } \\
\text { transition*** }\end{array}$ & 0 & 0 & 0 & 20 & 0 & 0 & 4 & 0 & 0 \\
\hline Eriophorum spp. & Eri_spp & $\begin{array}{c}\text { pond/rp- } \\
\text { transition*** }\end{array}$ & 10 & 0 & 0 & 37.5 & 0 & 0 & 20 & 0 & 0 \\
\hline Fabaceae & Fabaceae & $\operatorname{rim} * *$ & 10 & 0 & 0 & 3 & 0 & 0 & 3 & 0 & 0 \\
\hline Gentiana plebeja & Gen_ple & - & 3 & 0 & 0 & 0 & 0 & 0 & 0 & 0 & 0 \\
\hline Lagotis minor & Lag_min & $\operatorname{rim} * * *$ & 4 & 0 & 0 & 0 & 0 & 0 & 0 & 0 & 0 \\
\hline Larix gmelinii & Lar_gme & - & 62.5 & 0 & 0 & 87.5 & 0 & 0 & 0 & 0 & 0 \\
\hline Ledum palustre & Led_pal & rim* & 37.5 & 0 & 0 & 10 & 0 & 0 & 0 & 0 & 0 \\
\hline Luzula kjellmaniana & Luz_kje & $\operatorname{rim}^{* * *}$ & 4 & 0 & 0 & 0 & 0 & 0 & 0 & 0 & 0 \\
\hline
\end{tabular}




\begin{tabular}{|c|c|}
\hline Menyanthes trifoliata & Men_tri \\
\hline Micranthes hieracifolia & Mic_hie \\
\hline Minuartia arctica & Min_arc \\
\hline Oxycoccus palustris & Oxy_pal \\
\hline Pedicularis spp. & Ped_spp \\
\hline Poa spp. & Poa_spp \\
\hline Polygonum spp. & Pol_spp \\
\hline Pyrola sp. & Pyr_sp \\
\hline Rubus chamaemorus & Rub_cha \\
\hline Salix spp. & Sal_spp \\
\hline Saxifraga foliolosa & Sax_fol \\
\hline Saxifraga hirculus & Sax_hir \\
\hline Saxifraga nelsoniana & Sax_nel \\
\hline Saxifraga tenuis & Sax_ten \\
\hline Tofieldia coccinea & Tof_coc \\
\hline Vaccinium uliginosum & Vac_uli \\
\hline Vaccinium vitis-idaea & Vac_vitida \\
\hline Valeriana capitata & Val_cap \\
\hline \multicolumn{2}{|l|}{ non-vascular plants } \\
\hline Equisetum spp. & Equ_spp \\
\hline lichens & lichens \\
\hline \multicolumn{2}{|l|}{ bryophytes } \\
\hline Abietinella abietina & Abi_abi \\
\hline Aneura pinguis & Ane_pin \\
\hline Aulacomnium palustre & Aul_pal \\
\hline Aulacomnium turgidum & Aul_tur \\
\hline Brachythecium albicans & Bra_alb \\
\hline Bryum spp. & Bry_spp \\
\hline Calliergon giganteum & Cal_gig \\
\hline Calliergon megalophyllum & Cal_meg \\
\hline
\end{tabular}

\begin{tabular}{|c|c|c|c|c|c|c|c|c|c|}
\hline pond** & 0 & 0 & 0 & 0 & 0 & 0 & 37.5 & 0 & 0 \\
\hline- & 4 & 0 & 0 & 0 & 0 & 0 & 0 & 0 & 0 \\
\hline $\operatorname{rim} * *$ & 3 & 0 & 0 & 0 & 0 & 0 & 0 & 0 & 0 \\
\hline- & 4 & 0 & 0 & 3 & 0 & 0 & 0 & 0 & 0 \\
\hline- & 4 & 0 & 0 & 3 & 0 & 0 & 3 & 0 & 0 \\
\hline$\left(\operatorname{rim}^{* * *}\right)$ & 20 & 0 & 0 & 0 & 0 & 0 & 0 & 0 & 0 \\
\hline (pond/rim**) & 20 & 0 & 0 & 10 & 0 & 0 & 20 & 0 & 0 \\
\hline $\operatorname{rim} * * *$ & 4 & 0 & 0 & 3 & 0 & 0 & 0 & 0 & 0 \\
\hline rim* & 20 & 0 & 0 & 0 & 0 & 0 & 0 & 0 & 0 \\
\hline $\begin{array}{c}(\mathrm{rim} / \mathrm{rp}- \\
\text { transition } * * *)\end{array}$ & 20 & 0 & 0.5 & 20 & 0 & 0 & 10 & 0 & 0 \\
\hline- & 0 & 0 & 0 & 0 & 0 & 0 & 0.5 & 0 & 0 \\
\hline $\operatorname{rim} * *$ & 4 & 0 & 0 & 3 & 0 & 0 & 0 & 0 & 0 \\
\hline $\operatorname{rim} * * *$ & 4 & 0 & 0 & 0 & 0 & 0 & 0 & 0 & 0 \\
\hline- & 3 & 0 & 0 & 3 & 0 & 0 & 0 & 0 & 0 \\
\hline- & 0 & 0 & 0 & 0.5 & 0 & 0 & 0 & 0 & 0 \\
\hline $\operatorname{rim} * * *$ & 37.5 & 0 & 0 & 20 & 0 & 0 & 0.5 & 0 & 0 \\
\hline $\operatorname{rim} * * *$ & 20 & 0 & 0 & 3 & 0 & 0 & 0 & 0 & 0 \\
\hline $\operatorname{rim} * * *$ & 4 & 0 & 0 & 0.5 & 0 & 0 & 0 & 0 & 0 \\
\hline & 4 & 0 & 0 & 3 & 0 & 0 & 0 & 0 & 0 \\
\hline & 4 & 0 & 0 & 10 & 0 & 0 & 0 & 0 & 0 \\
\hline- & 4 & 0 & 0 & 4 & 0 & 0 & 0 & 0 & 0 \\
\hline rp-transition $* * *$ & 3 & 0 & 0 & 4 & 0 & 0 & 3 & 0 & 0 \\
\hline $\mathrm{rim} / \mathrm{rp}$-transition $* * *$ & 62.5 & 0 & 4 & 37.5 & 0 & 0 & 37.5 & 0 & 0 \\
\hline $\mathrm{rim} / \mathrm{rp}$-transition*** & 62.5 & 0 & 3 & 62.5 & 0 & 0 & 10 & 0 & 0 \\
\hline rim* & 4 & 0 & 0 & 3 & 0 & 0 & 0 & 0 & 0 \\
\hline rim/rp-transition** & 4 & 0 & 0 & 10 & 0 & 0 & 4 & 0 & 0 \\
\hline pond $* * *$ & 0 & 0 & 0 & 10 & 0 & 0 & 87.5 & 0 & 0 \\
\hline- & 20 & 0 & 0 & 20 & 0 & 0 & 20 & 0 & 0 \\
\hline
\end{tabular}




\begin{tabular}{|c|c|c|c|c|c|c|c|c|c|c|}
\hline Calliergon richardsonii & Cal_ric & pond/rp-transition* & 10 & 0 & 0 & 37.5 & 0 & 0 & 20 & 0 \\
\hline Calliergon stramineum & Cal_str & - & 4 & 0 & 0 & 4 & 0 & 0 & 0 & 0 \\
\hline Calliergon trifarium & Cal_tri & rp-transition** & 4 & 0 & 0 & 4 & 0 & 0 & 4 & 0 \\
\hline Campylium stellatum agg. & Cam_ste_agg & - & 20 & 0 & 0 & 4 & 0 & 0 & 20 & 0 \\
\hline Cirriphyllum cirrosum & Cir_cir & - & 4 & 0 & 0 & 4 & 0 & 0 & 0 & 0 \\
\hline Climacium dendroides & Cli_den & $\operatorname{rim} * * *$ & 4 & 0 & 0 & 0 & 0 & 0 & 0 & 0 \\
\hline Dicranum spp. & Dic_spp & $\operatorname{rim} * *$ & 20 & 0 & 4 & 20 & 0 & 0 & 10 & 0 \\
\hline Distichium capillaceum & Dis_cap & - & 4 & 0 & 0 & 4 & 0 & 0 & 3 & 0 \\
\hline Drepanocladus spp. & Dre_spp & - & 20 & 0 & 0.5 & 87.5 & 0 & 10 & 87.5 & 0 \\
\hline Entodon concinnus & Ent_con & $\operatorname{rim} * * *$ & 4 & 0 & 0 & 0 & 0 & 0 & 0 & 0 \\
\hline Fissidens adianthoides & Fis_adi & - & 4 & 0 & 0 & 0 & 0 & 0 & 0 & 0 \\
\hline Herzogiella seligeri & Her_sel & - & 4 & 0 & 0 & 0 & 0 & 0 & 0 & 0 \\
\hline Herzogiella turfacea & Her_tur & - & 3 & 0 & 0 & 0 & 0 & 0 & 0 & 0 \\
\hline Hylocomium splendens & Hyl_spl & $\operatorname{rim} * * *$ & 87.5 & 0 & 20 & 20 & 0 & 0 & 0 & 0 \\
\hline Hypnum spp. & Hyp_spp & - & 4 & 0 & 0 & 4 & 0 & 0 & 0 & 0 \\
\hline Liverwort (big) & Liv_big & rim/rp-transition** & 37.5 & 0 & 0 & 10 & 0 & 0 & 4 & 0 \\
\hline Liverwort (little) & Liv_lit & rim/rp-transition** & 4 & 0 & 0 & 10 & 0 & 0 & 0.5 & 0 \\
\hline Meesia triquetra & Mee_tri & pond/rp-transition* & 10 & 0 & 0 & 10 & 0 & 0 & 10 & 0 \\
\hline Meesia uliginosa & Mee_uli & - & 4 & 0 & 0 & 4 & 0 & 0 & 4 & 0 \\
\hline Mnium spinosum & Mni_spi & - & 3 & 0 & 0 & 0 & 0 & 0 & 0 & 0 \\
\hline Mnium spp. & Mni_spp & - & 4 & 0 & 0 & 10 & 0 & 0 & 4 & 0 \\
\hline Myurella sibirica & Myu_sib & - & 4 & 0 & 0 & 0 & 0 & 0 & 0 & 0 \\
\hline Oncophorus wahlenbergii & Onc_wah & - & 4 & 0 & 0 & 10 & 0 & 0 & 4 & 0 \\
\hline Orthothecium chryseum & Ort_chr & - & 4 & 0 & 0 & 20 & 0 & 0 & 4 & 0 \\
\hline Philonotis fontana & Phi_fon & - & 4 & 0 & 0 & 0 & 0 & 0 & 0 & 0 \\
\hline Ptilidium pulcherrimum & Pit_pul & - & 4 & 0 & 0 & 4 & 0 & 0 & 0 & 0 \\
\hline Pleurozium schreberi & Ple_sch & $\operatorname{rim} * * *$ & 20 & 0 & 0 & 10 & 0 & 0 & 0 & 0 \\
\hline Polytrichum spp. & Poly_spp & rim/rp-transition** & 10 & 0 & 0 & 4 & 0 & 0 & 3 & 0 \\
\hline Ptilium crista-castrensis & Pti_cri_cas & - & 3 & 0 & 0 & 0 & 0 & 0 & 0 & 0 \\
\hline Racomitrium canescens & Rac_can & - & 0 & 0 & 0 & 3 & 0 & 0 & 0 & 0 \\
\hline
\end{tabular}




\begin{tabular}{|c|c|c|c|c|c|c|c|c|c|c|c|}
\hline $\begin{array}{l}\text { Sarmenthypnum } \\
\text { sarmentosum }\end{array}$ & Sar_sar & rp-transition* & 3 & 0 & 0 & 10 & 0 & 0 & 0 & 0 & 0 \\
\hline Scorpidium scorpioides & Sco_sco & $\begin{array}{c}\text { pond/rp- } \\
\text { transition*** }\end{array}$ & 87.5 & 0 & 0 & 87.5 & 0 & 15 & 87.5 & 0 & 10 \\
\hline Scorpidium turgescens & Sco_tur & rim/rp-transition* & 4 & 0 & 0 & 4 & 0 & 0 & 0 & 0 & 0 \\
\hline Sphagnum spp. & Sph_spp & rim/rp-transition $* *$ & 87.5 & 0 & 0 & 20 & 0 & 0 & 0 & 0 & 0 \\
\hline Timmia norvegica & Tim_nor & - & 4 & 0 & 0 & 0 & 0 & 0 & 0 & 0 & 0 \\
\hline Tomentypnum nitens & Tom_nit & $\mathrm{rim} / \mathrm{rp}$-transition $* * *$ & 62.5 & 0 & 4 & 62.5 & 0 & 0 & 20 & 0 & 0 \\
\hline Tortella fragilis & Tor_fra & - & 4 & 0 & 0 & 0 & 0 & 0 & 0 & 0 & 0 \\
\hline Tortula ruralis & Tor_rur & - & 3 & 0 & 0 & 0 & 0 & 0 & 0 & 0 & 0 \\
\hline
\end{tabular}

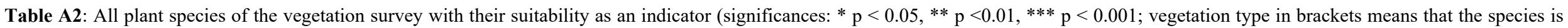
potentially not feasible or is part of a species group with a large range of local preferences) and their cover for the vegetation types along the tree-line transect.

\begin{tabular}{|c|c|c|c|c|c|c|c|c|c|c|c|}
\hline \multirow[t]{2}{*}{ species } & \multirow[t]{2}{*}{ abbr. } & \multirow{2}{*}{$\begin{array}{l}\text { indicator zonal } \\
\text { vegetation type }\end{array}$} & \multicolumn{3}{|c|}{ open forest } & \multicolumn{3}{|c|}{$\begin{array}{c}\text { cover }[\%] \\
\text { forest-tundra intersection }\end{array}$} & \multicolumn{3}{|c|}{ tundra } \\
\hline & & & $\max$ & $\min$ & median & $\max$ & $\min$ & median & $\max$ & $\min$ & media \\
\hline \multicolumn{12}{|l|}{ vascular plants } \\
\hline Alnus viridis spp. fruticosa & Aln_fru & $\mathrm{ft}$-intersection $* * *$ & 0 & 0 & 0 & 37.5 & 0 & 0 & 0 & 0 & 0 \\
\hline Andromeda polifolia & And_pol & ft-intersection $* * *$ & 4 & 0 & 0 & 4 & 0 & 0 & 0 & 0 & 0 \\
\hline Arctostaphylos alpina & Arc_alp & $\mathrm{ft}$-intersection $* * *$ & 0 & 0 & 0 & 10 & 0 & 0 & 3 & 0 & 0 \\
\hline Asteraceae & Asteraceae & (tundra**) & 0 & 0 & 0 & 0 & 0 & 0 & 3 & 0 & 0 \\
\hline Betula nana & Bet_nan & $\begin{array}{l}\text { ft-intersection/ open } \\
\text { forest* }\end{array}$ & 37.5 & 0 & 0 & 37.5 & 0 & 0 & 20 & 0 & 0 \\
\hline Caltha palustris & Cal_pal & - & 0 & 0 & 0 & 0 & 0 & 0 & 0.5 & 0 & 0 \\
\hline Carex spp. & Car_spp & $\begin{array}{l}\text { (ft-intersection/ } \\
\text { tundra***) }\end{array}$ & 0 & 0 & 0 & 62.5 & 0 & 10 & 62.5 & 0 & 10 \\
\hline Caryophyllaceae & $\begin{array}{l}\text { Caryo- } \\
\text { phyllaceae }\end{array}$ & (ft-intersection*) & 0 & 0 & 0 & 3 & 0 & 0 & 3 & 0 & 0 \\
\hline $\begin{array}{l}\text { Chrysosplenium } \\
\text { alternifolium }\end{array}$ & Chr_alt & - & 0 & 0 & 0 & 0 & 0 & 0 & 3 & 0 & 0 \\
\hline Comarum palustre & Com_pal & - & 0 & 0 & 0 & 10 & 0 & 0 & 10 & 0 & 0 \\
\hline Draba alpina & Dra_alp & - & 0 & 0 & 0 & 0 & 0 & 0 & 3 & 0 & 0 \\
\hline
\end{tabular}




\begin{tabular}{|c|c|c|c|c|c|c|c|c|c|c|c|}
\hline Dryas punctata & Dry_pun & $\begin{array}{l}\mathrm{ft} \text {-intersection/ } \\
\text { tundra** }\end{array}$ & 0 & 0 & 0 & 20 & 0 & 0 & 20 & 0 & 0 \\
\hline Empetrum nigrum & Emp_nig & - & 0 & 0 & 0 & 10 & 0 & 0 & 0 & 0 & 0 \\
\hline Epilobium sp. & Epi_sp & (tundra***) & 3 & 0 & 0 & 0 & 0 & 0 & 20 & 0 & 0 \\
\hline Eriophorum spp. & Eri_spp & (open forest $* * *$ ) & 37.5 & 0 & 3 & 37.5 & 0 & 0 & 20 & 0 & 0 \\
\hline Fabaceae & Fabaceae & tundra* & 0 & 0 & 0 & 0.5 & 0 & 0 & 10 & 0 & 0 \\
\hline Gentiana plebeja & Gen_ple & - & 0 & 0 & 0 & 0 & 0 & 0 & 3 & 0 & 0 \\
\hline Lagotis minor & Lag_min & (tundra*) & 0 & 0 & 0 & 0 & 0 & 0 & 4 & 0 & 0 \\
\hline Larix gmelinii & Lar_gme & (ft-intersection*) & 0 & 0 & 0 & 87.5 & 0 & 0 & 0 & 0 & 0 \\
\hline Ledum palustre & Led_pal & open forest ${ }^{* * *}$ & 37.5 & 0 & 0 & 10 & 0 & 0 & 0 & 0 & 0 \\
\hline Luzula kjellmaniana & Luz_kje & tundra*** & 0 & 0 & 0 & 0 & 0 & 0 & 4 & 0 & 0 \\
\hline Menyanthes trifoliata & Men_tri & open forest $* * *$ & 37.5 & 0 & 0 & 0 & 0 & 0 & 0 & 0 & 0 \\
\hline Micranthes hieracifolia & Mic_hie & - & 0 & 0 & 0 & 0 & 0 & 0 & 4 & 4 & 0 \\
\hline Minuartia arctica & Min_arc & tundra* & 0 & 0 & 0 & 0 & 0 & 0 & 3 & 0 & 0 \\
\hline Oxycoccus palustris & Oxy_pal & open forest ${ }^{* * *}$ & 4 & 0 & 0 & 0 & 0 & 0 & 0 & 0 & 0 \\
\hline Pedicularis spp. & Ped_spp & $\begin{array}{l}\text { ft-intersection/ } \\
\text { tundra*** }\end{array}$ & 0 & 0 & 0 & 4 & 0 & 0 & 3 & 0 & 0 \\
\hline Poa spp. & Poa_spp & - & 3 & 0 & 0 & 20 & 0 & 0 & 4 & 0 & 0 \\
\hline Polygonum spp. & Pol_spp & $\begin{array}{l}\text { (ft-intersection/ } \\
\text { tundra**) }\end{array}$ & 0 & 0 & 0 & 20 & 0 & 0 & 4 & 0 & 0 \\
\hline Pyrola sp. & Pyr_sp & $\begin{array}{l}\text { (ft-intersection/ } \\
\text { tundra*) }\end{array}$ & 0 & 0 & 0 & 4 & 0 & 0 & 3 & 0 & 0 \\
\hline Rubus chamaemorus & Rub_cha & open forest** & 20 & 0 & 0 & 10 & 0 & 0 & 0 & 0 & 0 \\
\hline Salix spp. & Sal_spp & $\begin{array}{l}\text { (ft-intersection/ } \\
\text { tundra***) }\end{array}$ & 0 & 0 & 0 & 20 & 0 & 0 & 20 & 0 & 0 \\
\hline Saxifraga foliolosa & Sax_fol & - & 0 & 0 & 0 & 0 & 0 & 0 & 0.5 & 0 & 0 \\
\hline Saxifraga hirculus & Sax_hir & tundra** & 0 & 0 & 0 & 0 & 0 & 0 & 4 & 0 & 0 \\
\hline Saxifraga nelsoniana & Sax_nel & tundra** & 0 & 0 & 0 & 0 & 0 & 0 & 4 & 0 & 0 \\
\hline Saxifraga tenuis & Sax_ten & - & 0 & 0 & 0 & 0 & 0 & 0 & 3 & 0 & 0 \\
\hline Tofieldia coccinea & Tof_coc & - & 0 & 0 & 0 & 0 & 0 & 0 & 0.5 & 0 & 0 \\
\hline Vaccinium uliginosum & Vac_uli & $\begin{array}{l}\mathrm{ft}-\text { intersection/ open } \\
\text { forest }^{* * *}\end{array}$ & 10 & 0 & 0 & 37.5 & 0 & 0 & 0 & 0 & 0 \\
\hline
\end{tabular}




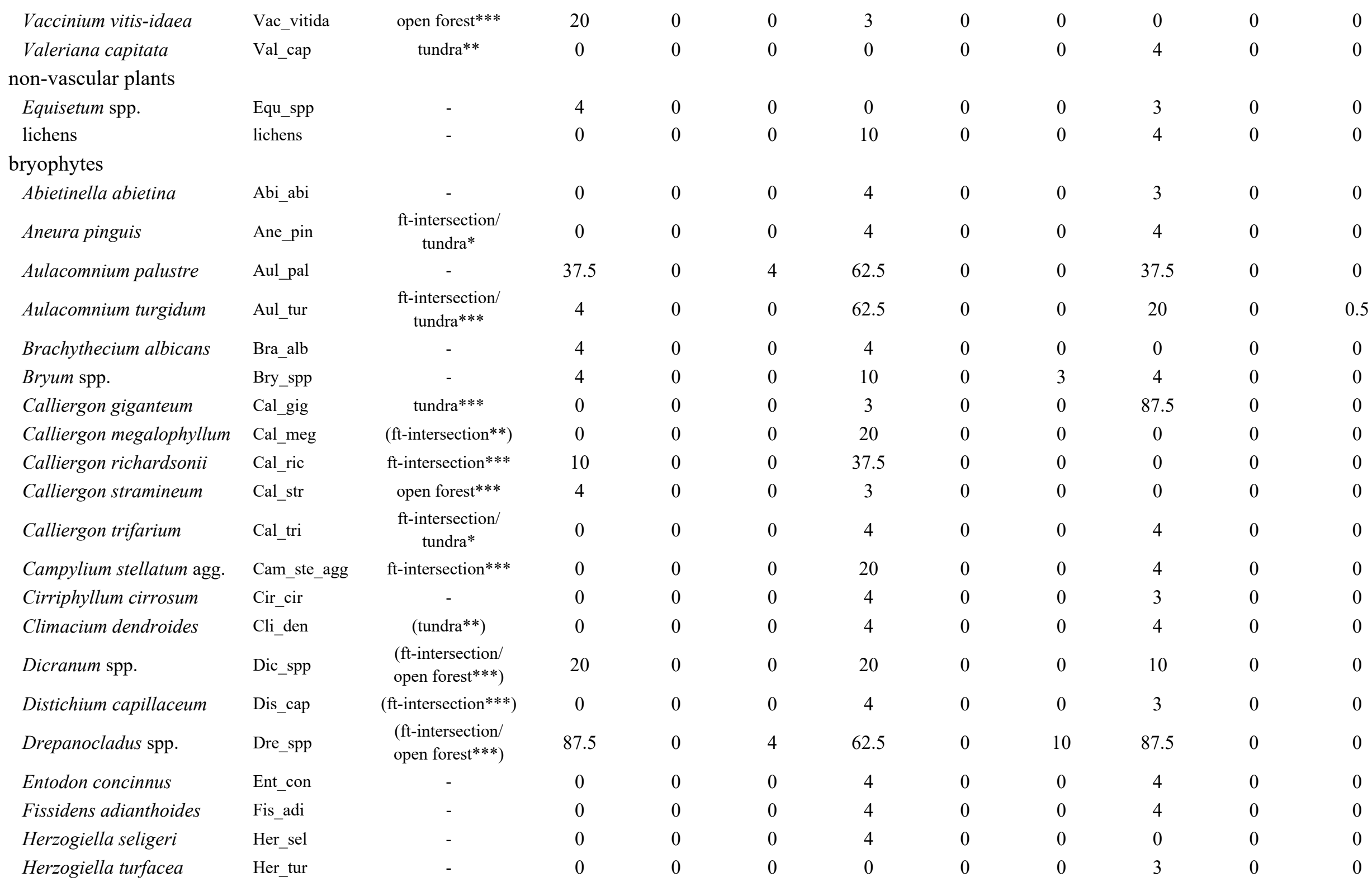




\begin{tabular}{|c|c|c|c|c|c|c|c|c|c|c|c|}
\hline Hylocomium splendens & Hyl_spl & - & 62.5 & 0 & 0 & 62.5 & 0 & 0 & 87.5 & 0 & 0 \\
\hline Hурпит spp. & Hyp_spp & (ft-intersection*) & 0 & 0 & 0 & 4 & 0 & 0 & 0 & 0 & 0 \\
\hline Liverwort (big) & Liv_big & $(\mathrm{ft}-$ intersection $* * *)$ & 0 & 0 & 0 & 37.5 & 0 & 0 & 0 & 0 & 0 \\
\hline Liverwort (little) & Liv_lit & - & 4 & 0 & 0 & 10 & 0 & 0 & 4 & 0 & 0 \\
\hline Meesia triquetra & Mee_tri & $\begin{array}{l}\text { ft-intersection/ } \\
\text { tundra*** }\end{array}$ & 0 & 0 & 0 & 10 & 0 & 0 & 10 & 0 & 0 \\
\hline Meesia uliginosa & Mee_uli & - & 0 & 0 & 0 & 4 & 0 & 0 & 4 & 0 & 0 \\
\hline Mnium spinosum & Mni_spi & - & 0 & 0 & 0 & 0 & 0 & 0 & 3 & 0 & 0 \\
\hline Mnium spp. & Mni_spp & $\begin{array}{l}\mathrm{ft} \text {-intersection/ } \\
\text { tundra* }\end{array}$ & 4 & 0 & 0 & 10 & 0 & 0 & 10 & 0 & 0 \\
\hline Myurella sibirica & Myu_sib & - & 0 & 0 & 0 & 4 & 0 & 0 & 0 & 0 & 0 \\
\hline Oncophorus wahlenbergii & Onc_wah & ft-intersection** & 0 & 0 & 0 & 10 & 0 & 0 & 3 & 0 & 0 \\
\hline Orthothecium chryseum & Ort_chr & $\mathrm{ft}$-intersection** & 0 & 0 & 0 & 20 & 0 & 0 & 0 & 0 & 0 \\
\hline Philonotis fontana & Phi_fon & - & 0 & 0 & 0 & 0 & 0 & 0 & 4 & 0 & 0 \\
\hline Ptilidium pulcherrimum & Pit_pul & - & 4 & 0 & 0 & 4 & 0 & 0 & 3 & 0 & 0 \\
\hline Pleurozium schreberi & Ple_sch & open forest ${ }^{* * *}$ & 20 & 0 & 0 & 0 & 0 & 0 & 10 & 0 & 0 \\
\hline Polytrichum spp. & Poly_spp & $\begin{array}{c}\text { open } \\
\text { forest/tundra*** }\end{array}$ & 10 & 0 & 0 & 3 & 0 & 0 & 10 & 0 & 0 \\
\hline Ptilium crista-castrensis & Pti_cri_cas & - & 3 & 0 & 0 & 0 & 0 & 0 & 0 & 0 & 0 \\
\hline Racomitrium canescens & Rac_can & - & 0 & 0 & 0 & 0 & 0 & 0 & 3 & 0 & 0 \\
\hline $\begin{array}{l}\text { Sarmenthypnum } \\
\text { sarmentosum }\end{array}$ & Sar_sar & - & 3 & 0 & 0 & 3 & 0 & 0 & 10 & 0 & 0 \\
\hline Scorpidium scorpioides & Sco_sco & $\begin{array}{l}\text { ft-intersection/ } \\
\text { tundra*** }\end{array}$ & 0 & 0 & 0 & 87.5 & 0 & 4 & 87.5 & 0 & 4 \\
\hline Scorpidium turgescens & Sco_tur & $\mathrm{ft}$-intersection $* * *$ & 0 & 0 & 0 & 4 & 0 & 0 & 0 & 0 & 0 \\
\hline Sphagnum spp. & Sph_spp & open forest $* * *$ & 87.5 & 0 & 0 & 10 & 0 & 0 & 37.5 & 0 & 0 \\
\hline Timmia norvegica & Tim_nor & - & 0 & 0 & 0 & 0 & 0 & 0 & 4 & 0 & 0 \\
\hline Tomentypnum nitens & Tom_nit & $\begin{array}{l}\mathrm{ft} \text {-intersection/ } \\
\text { tundra*** }\end{array}$ & 3 & 0 & 0 & 62.5 & 0 & 0.5 & 62.5 & 0 & 0 \\
\hline Tortella fragilis & Tor_fra & - & 0 & 0 & 0 & 0 & 0 & 0 & 4 & 0 & 0 \\
\hline Tortula ruralis & Tor_rur & - & 0 & 0 & 0 & 0 & 0 & 0 & 3 & 0 & 0 \\
\hline
\end{tabular}

